\title{
ATF Benchmark Problems
}

Eva Davidson, ORNL

Fausto Franceschini, Westinghouse Kang Seog Kim, ORNL

April 30, 2019
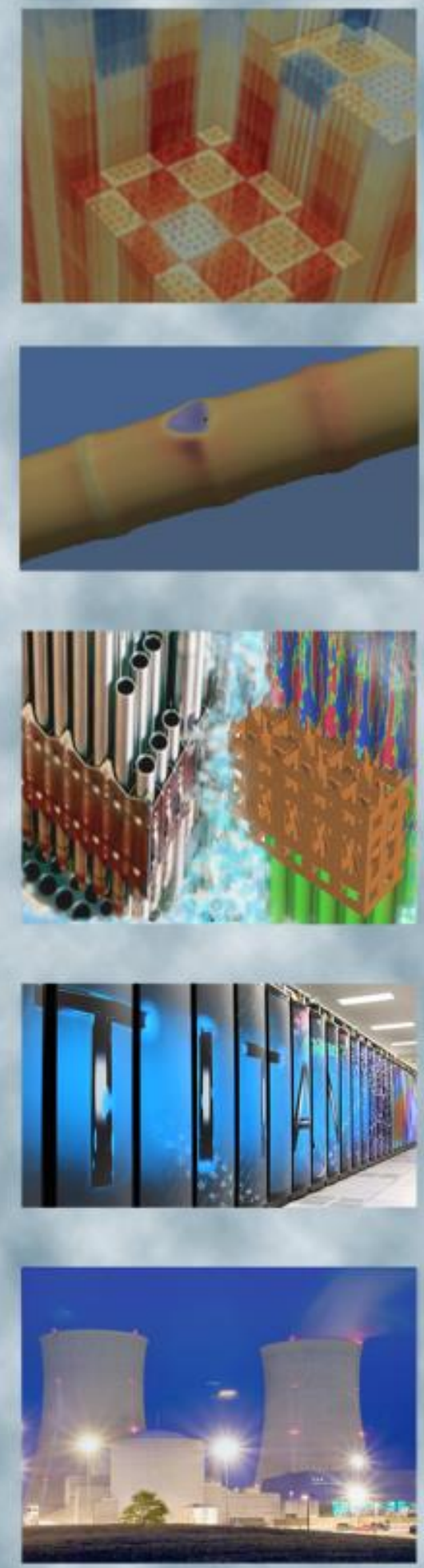


\title{
DOCUMENT AVAILABILITY
}

Reports produced after January 1, 1996, are generally available free via US Department of Energy (DOE) SciTech Connect.

Website www.osti.gov

Reports produced before January 1, 1996, may be purchased by members of the public from the following source:

\author{
National Technical Information Service \\ 5285 Port Royal Road \\ Springfield, VA 22161 \\ Telephone 703-605-6000 (1-800-553-6847) \\ TDD 703-487-4639 \\ Fax 703-605-6900 \\ E-mail info@ntis.gov \\ Website http://classic.ntis.gov/
}

Reports are available to DOE employees, DOE contractors, Energy Technology Data Exchange representatives, and International Nuclear Information System representatives from the following source:

Office of Scientific and Technical Information

PO Box 62

Oak Ridge, TN 37831

Telephone 865-576-8401

Fax 865-576-5728

E-mail reports@osti.gov

Website http://www.osti.gov/contact.html

This report was prepared as an account of work sponsored by an
agency of the United States Government. Neither the United States
Government nor any agency thereof, nor any of their employees, makes
any warranty, express or implied, or assumes any legal liability or
responsibility for the accuracy, completeness, or usefulness of any
information, apparatus, product, or process disclosed, or represents that
its use would not infringe privately owned rights. Reference herein to
any specific commercial product, process, or service by trade name,
trademark, manufacturer, or otherwise, does not necessarily constitute
or imply its endorsement, recommendation, or favoring by the United
States Government or any agency thereof. The views and opinions of
authors expressed herein do not necessarily state or reflect those of the
United States Government or any agency thereof.


REVISION LOG

\begin{tabular}{|c|c|c|l|}
\hline Revision & Date & $\begin{array}{c}\text { Affected } \\
\text { Pages }\end{array}$ & \multicolumn{1}{c|}{ Revision Description } \\
\hline 0 & $04 / 30 / 2019$ & All & Initial Release \\
\hline & & & \\
\hline & & & \\
\hline & & & \\
\hline
\end{tabular}

\section{Document pages that are:}

Unlimited

All

Export Controlled None

IP/Proprietary/NDA Controlled__None

Sensitive Controlled__None

This report was prepared as an account of work sponsored by an agency of the United States Government. Neither the United States Government nor any agency thereof, nor any of their employees, makes any warranty, express or implied, or assumes any legal liability or responsibility for the accuracy, completeness, or usefulness of any information, apparatus, product, or process disclosed, or represents that its use would not infringe privately owned rights. Reference herein to any specific commercial product, process, or service by trade name, trademark, manufacturer, or otherwise, does not necessarily constitute or imply its endorsement, recommendation, or favoring by the United States Government or any agency thereof. The views and opinions of authors expressed herein do not necessarily state or reflect those of the United States Government or any agency thereof.

\section{Requested Distribution:}

To: N/A

Copy: N/A 



\section{EXECUTIVE SUMMARY}

In fiscal year 2018, the US Nuclear Regulatory Commission (NRC) expressed an interest in using the US Department of Energy (DOE) Office of Nuclear Energy (NE) advanced modeling and simulation tools to evaluate advanced fuel concepts such as accident-tolerant fuel (ATF). This interest evolved into formal cooperation between DOE and NRC to ensure that advanced modeling and simulation (M\&S) capability is available to the NRC for the analyses of ATF concepts. The Consortium for Advanced Simulation of Light Water Reactors (CASL) has developed, applied, and deployed advanced modeling and simulation capabilities to enhance the operational performance, efficiency, and safety of light water reactors (LWRs). As a result of this cooperative effort between DOE and NRC, potential ATF concepts of interest to the industry were identified and simulated with CASL's Virtual Environment for Reactor Applications (VERA) for 2D pressurized water reactor (PWR) $17 \times 17$ lattices. Four ATF concepts were identified by CASL's Westinghouse collaborators, and the benchmark specifications for these ATF concepts were generated as presented in this report. These benchmark problems were set up to test the ability of VERA to simulate these ATF concepts, and the results generated by VERA were compared against two Monte Carlo codes: (1) Serpent, which was developed at VTT Technical Research Centre of Finland Ltd, and (2) Shift, which was developed at Oak Ridge National Laboratory (ORNL). The depletion parameters and flags used to run these models differ between all three codes, and there were differences seen between VERA, Shift, and Serpent, but overall, the agreement shown was considered sufficient to progress to core modeling and evaluation of these ATF concepts using VERA. The differences identified in this document require further investigation by modeling single fuel pin depletion to compare the isotopic evolution of the fuel during a depletion calculation. Prior depletion benchmarking efforts between VERA and Shift have shown closer agreement for $\mathrm{UO}_{2}$, so recent changes to the code and the data should be investigated to identify the cause of these differences. 


\section{CONTENTS}

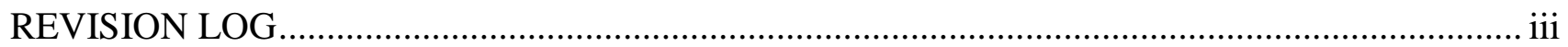

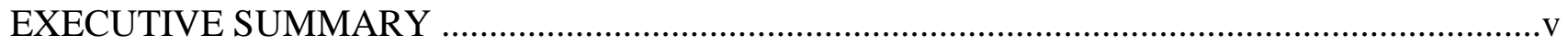

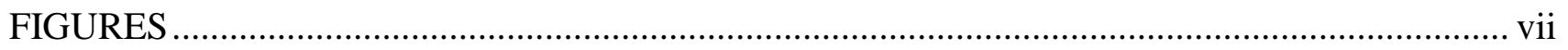

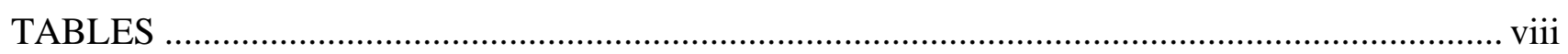

ACRONYMS and ABBREVIATIONS ............................................................................. ix

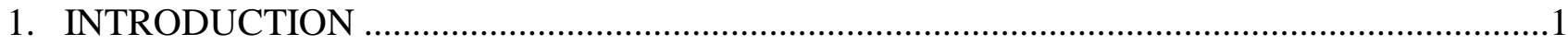

2. ATF CONCEPTS

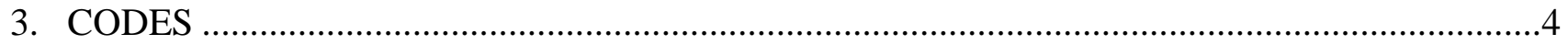

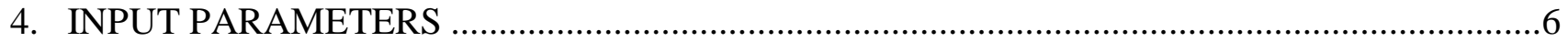

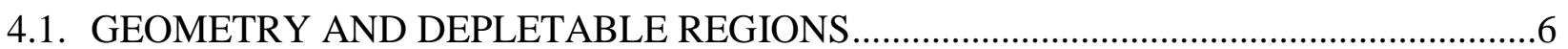

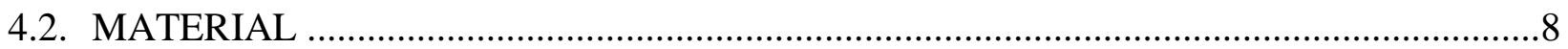

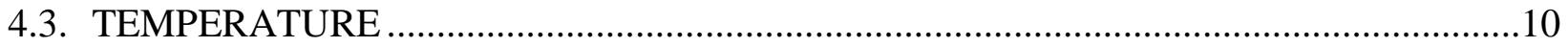

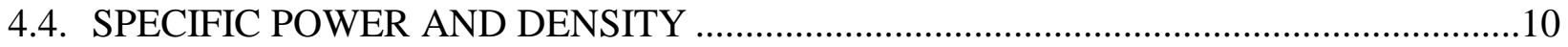

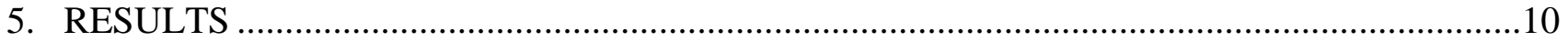

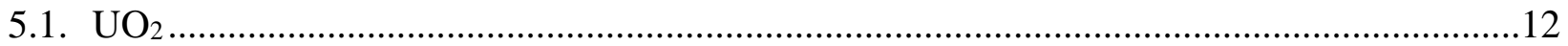

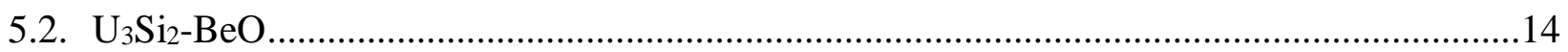

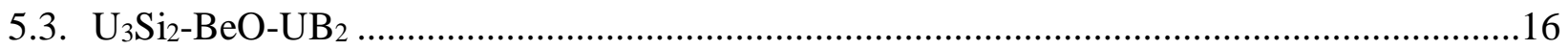

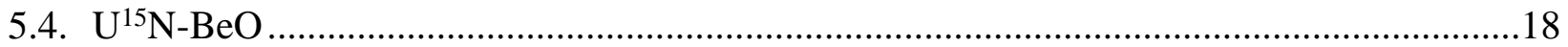

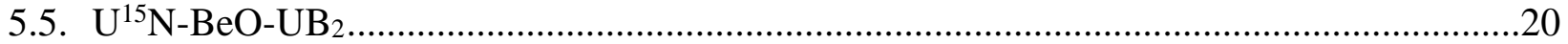

5.6. DIFFERENCE BETWEEN SHIFT AND SERPENT RESULTS ………….......................22

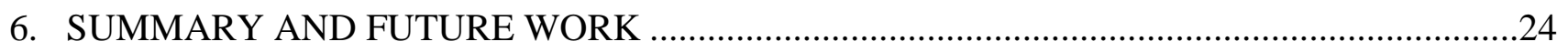

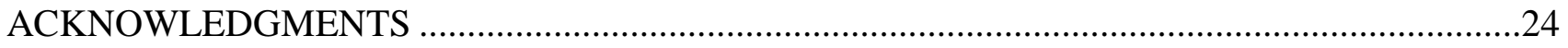

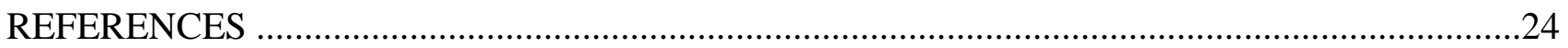




\section{FIGURES}

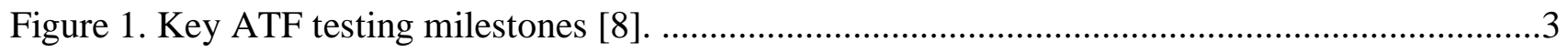

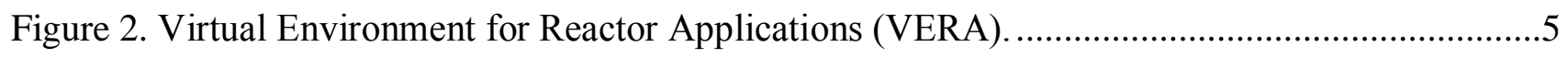

Figure 3. PWR lattice with three depletable fuel regions (zoomed in view of 2x2 pins).................7

Figure 4. PWR lattice with three depletable fuel regions. .......................................................11

Figure 5. Differences between Shift and Serpent results.....................................................12 


\section{TABLES}

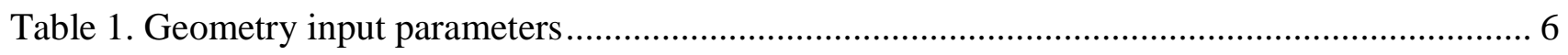

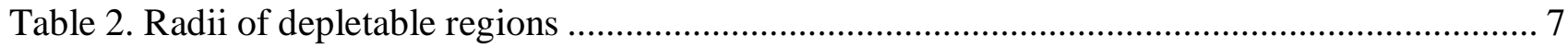

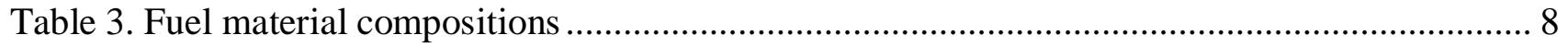

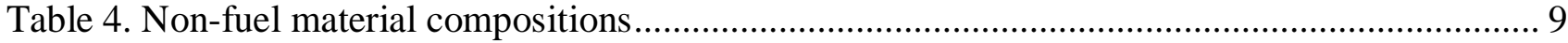

Table 5. Temperature of materials in each region ....................................................................... 10

Table 6. Specific power and density of materials in each region ............................................... 10

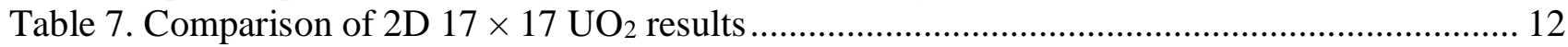

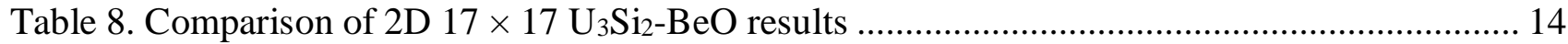

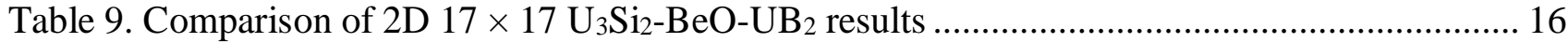

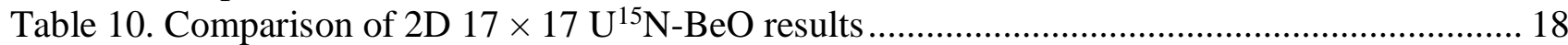

Table 11. Comparison of 2D $17 \times 17 \mathrm{U}^{15} \mathrm{~N}-\mathrm{BeO}-\mathrm{UB}_{2}$ results.................................................. 20

Table 12. Comparison of results from Shift and Serpent Monte Carlo codes ................................ 22 


\section{ACRONYMS and ABBREVIATIONS}

2D

two-dimensional

ATF

accident-tolerant fuel

ATR

Advanced Test Reactor

$\mathrm{BeO}$

beryllium oxide

$\mathrm{Cr}$

chromium

CASL

Consortium for Advanced Simulation of Light Water Reactors

CE

$\mathrm{CTF}$ continuous-energy (cross sections)

DOE

COBRA-TF

FY

US Department of Energy

GWd/MTU

fiscal year

HPC

INL

LFR

LTA

LWR

$M \& S$

NRC

NSSS

ORNL

PWR

$\mathrm{T} / \mathrm{H}$

$\mathrm{UB}_{2}$

$\mathrm{U}^{15} \mathrm{~N}$

gigawatt-days per metric ton of uranium

high-performance computer

Idaho National Laboratory

lead fuel rod

lead test assembly

light-water reactor

modeling and simulation

US Nuclear Regulatory Commission

nuclear steam supply system

Oak Ridge National Laboratory

pressurized water reactor

thermal hydraulics

uranium boride

uranium nitride

uranium dioxide

uranium silicide

$\mathrm{U}_{3} \mathrm{Si}_{2}$

Virtual Environment for Reactor Applications 



\section{INTRODUCTION}

The events at Fukushima Daiichi Nuclear Power Plant on March 2011 propelled the research and development of accident-tolerant fuel (ATF) for use in nuclear power plants. After these events, the United States Senate Appropriations Committee requested a report from the United States Department of Energy (DOE) regarding DOE's plan for developing ATF. In DOE's development plan [1], a 10-year effort beginning in 2012 was outlined from Phase 1 feasibility studies through Phase 3 commercialization with a lead test assembly (LTA) or a lead fuel rod (LFR) to be ready for insertion into a reactor by 2022 .

In fiscal year 2018, the US Nuclear Regulatory Commission (NRC) expressed an interest in using the DOE Office of Nuclear Energy (NE) advanced modeling and simulation (M\&S) tools to evaluate advanced fuel concepts such as ATF. This interest evolved into a formal cooperation between DOE and NRC to ensure that an effective M\&S capability is available for NRC analyses of ATF concepts [2].

Over the last 10 years, the DOE-funded Energy Innovation Hub, also known as the Consortium for Advanced Simulation of Light Water Reactors (CASL), has developed, applied and deployed advanced M\&S capabilities to enhance the operational performance, efficiency, and safety of light water reactors (LWRs). Due to the aging US nuclear fleet, CASL was initiated to improve the efficiency of nuclear power production, lower costs by enhancing the understanding of fuel performance and residence time in the nuclear reactor, enhance safety by studying new fuels that can endure severe conditions, and extend the life of existing reactors by predicting the lifetimes of key structural components [3].

As a result of the cooperation between DOE and NRC, potential ATF concepts of interest to the industry were identified and simulated with CASL's Virtual Environment for Reactor Applications (VERA) [4] for 2D pressurized water reactor (PWR) $17 \times 17$ lattices. Four ATF concepts were identified by CASL's Westinghouse collaborators, and benchmark problems were generated as presented in this report. These benchmark problems were set up to test the ability of VERA to simulate these ATF concepts, and the results generated by VERA were compared against two Monte Carlo codes: (1) Serpent [5], developed by the VTT Technical Research Centre of Finland Ltd, and Shift [6], which was developed at Oak Ridge National Laboratory (ORNL). 


\section{ATF CONCEPTS}

Several varieties of ATF concepts are under development in the nuclear industry and in academia. The three main nuclear fuel vendors in the US-Framatome, General Electric (GE) and Westinghouse - are all developing ATF concepts in close research and development partnership with DOE-NE. In January 2019, DOE-NE awarded \$111 million in funding through fiscal year 2021 to these three US fuel vendors to develop ATF [7]. The primary objectives of the DOE awards are detailed below [7]:

- GE will continue (1) development of iron chromium aluminum (FeCrAl) alloys cladding, (2) the development of its coating program for zirconium alloys, ARMOR, and (3) the study of uranium dioxide-based ceramic metal fuels;

- Framatome to continue (1) the development and deployment of chromium-coated zirconium alloy cladding with chromia-doped uranium oxide pellets $\left(\mathrm{Cr}-\mathrm{Cr}_{2} \mathrm{O}_{3}\right)$ and (2) expand development efforts on silicon carbide cladding concepts; and

- Westinghouse to continue the development of uranium silicide and doped uranium oxide fuel, also known as $A D O P T$ fuel, in chromium-coated zirconium alloy cladding, and (2) the development of silicon carbide cladding concepts.

For the first 14-month period of the award, the fuel vendors are required to [7] accomplish the following:

- Ensure that an initial LTA has been installed in a US commercial power plant

- Ensure that prototypic pin segments have been installed in the Idaho National Laboratory (INL) Advanced Test Reactor (ATR) water loop;

- Continue development of licensing approaches for the ATF concept, including the involvement of at least one nuclear power plant owner/operator per ATF concept

- Ensure interaction with the NRC for licensing of each concept

Figure 1 [8] shows key ATF testing milestones for the three US fuel vendors. LTAs are expected to be inserted by Framatome in Southern's Vogtle, GE in Exelon's Clinton, and Westinghouse in Exelon's Byron. 


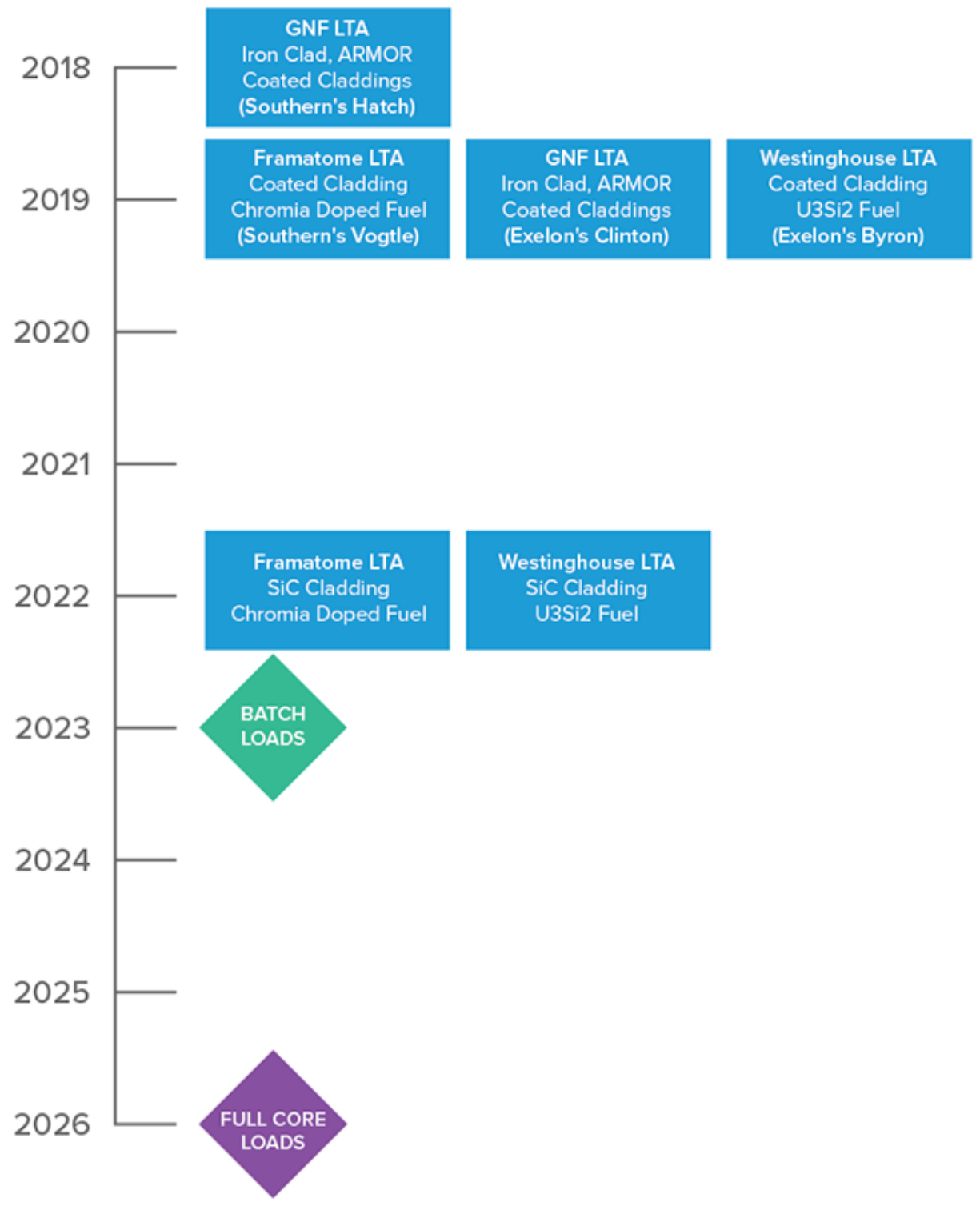

Figure 1. Key ATF testing milestones [8]. 
To facilitate the licensing of these ATF concepts, it is crucial for DOE-NE to cooperate with the NRC through CASL to identify any modeling and simulation gaps of ATF concepts. The advanced modeling and simulation capabilities developed within CASL can accelerate the design and testing of these advanced fuel concepts. The purpose of this document is to ensure that any modeling and simulation gaps for ATF in VERA are identified and that a set of benchmark problems are prescribed for testing the M\&S codes identified within this document. As these codes evolve and are updated, this document may be amended with revised results from the codes identified.

In developing this document, CASL's Westinghouse collaborators identified the following ATF concepts for PWRs as benchmark problems for M\&S tools:

- Uranium silicide $\left(\mathrm{U}_{3} \mathrm{Si}_{2}\right)$ and beryllium oxide $(\mathrm{BeO})$ fuel and chromium coated ZIRLO ${ }^{\circledR}$ cladding;

- $\mathrm{U}_{3} \mathrm{Si}_{2}$ with $\mathrm{BeO}$ doped with uranium boride $\left(\mathrm{UB}_{2}\right)$ and chromium-coated ZIRLO cladding;

- Uranium nitride $\left(\mathrm{U}^{15} \mathrm{~N}\right)$ with $\mathrm{BeO}$ and chromium-coated ZIRLO cladding;

- $\mathrm{U}^{15} \mathrm{~N}$ with $\mathrm{BeO}$ doped with $\mathrm{UB}_{2}$ and chromium-coated ZIRLO cladding

These concepts were developed by Westinghouse to enhance accident tolerance, to simplify designs for future nuclear steam supply systems (NSSSs), and to improve fuel costs, thereby incentivizing their use for utilities $[9,10]$. Currently, Westinghouse is developing $\mathrm{U}_{3} \mathrm{Si}_{2}$ pellets as its mid-term fuel product, whereas the waterproofed $\mathrm{U}^{15} \mathrm{~N}$ fuel is being considered as the long-term fuel product $[9,10]$. The chromium coating on zirconium cladding is expected to reduce oxidation and hydriding and to provide an improvement in temperature tolerance in severe accident scenarios. $\mathrm{U}_{3} \mathrm{Si}_{2}$ fuel provides a $17 \%$ increase in ${ }^{235} \mathrm{U}$ and an increase in thermal conductivity by a factor of $2-5$ as compared to $\mathrm{UO}_{2}[9,10]$. $\mathrm{U}^{15} \mathrm{~N}[9,10]$ fuel provides an increase in ${ }^{235} \mathrm{U}$ of $\sim 35 \%$ and an increase in thermal conductivity by factor of 5-10 [9,10]. Westinghouse is currently partnering with INL, Los Alamos National Laboratory (LANL), Texas A\&M University, and National Nuclear Laboratory (NNL) in the United Kingdom for the development and fabrication of waterproofed $\mathrm{U}_{3} \mathrm{Si}_{2}$ and $\mathrm{U}^{15} \mathrm{~N}$ fuel concepts [10]. The addition of $\mathrm{BeO}$ to $\mathrm{U}_{3} \mathrm{Si}_{2}$ and $\mathrm{UN}$ is intended to simulate addition of a fuel dopant, and the addition of $U$ dilutant will improve the high-temperature water resistance of these ATF concepts. ADOPT was not specifically benchmarked in this study due to its obvious similarity to $\mathrm{UO}_{2}$ fuel. Therefore, besides adding ADOPT to the related modeling capability in VERA, no specific benchmarking exercise has been devised for this option, as it is deemed to be already covered by the extensive benchmarking activities performed for $\mathrm{UO}_{2}$ fuel. The results from these ATF concept analyses are compared against $\mathrm{UO}_{2}$ results for a $17 \times 17$ Westinghouse PWR assembly.

\section{CODES}

M\&S tools used to simulate these benchmark problems were VERA, Serpent, and Shift. CASL's VERA offers unique capabilities that combine high-fidelity in-core and ex-core radiation transport. Figure 2 shows an overview of VERA, which is composed of multiple physics components for reactor simulation and direct coupling between these physics. A lot of attention is given to the usability of VERA and its parallel performance on high performance computer systems (HPCs). VERA's deterministic neutronics code MPACT [11] performs in-core radiation transport with temperature feedback using COBRA-TF (CTF) [12]. MPACT performs a direct whole-core 3D neutron transport calculation with 51 energy groups, explicit pin-by-pin powers with intra-pin distributions, explicit pin-by-pin depletion and decay at local conditions, and semi-explicit 3D reflector geometry. In addition to performing the neutron transport calculation, local thermalhydraulic $(\mathrm{T} / \mathrm{H})$ conditions for feedback are calculated using $\mathrm{CTF}$ with fuel temperatures for each 
rod, as well as sub-channel T/H with transient two-fluid, three-field (liquid film, liquid drops and vapor) solutions in coolant channels with cross-flow. ORIGEN [13] is used to perform isotopic depletion and decay, with 263 isotopes being tracked. MPACT can also perform a critical boron search, control rod movements, fuel shuffling, and in-core instrumentation response, as well as read and write restart files at various state points.

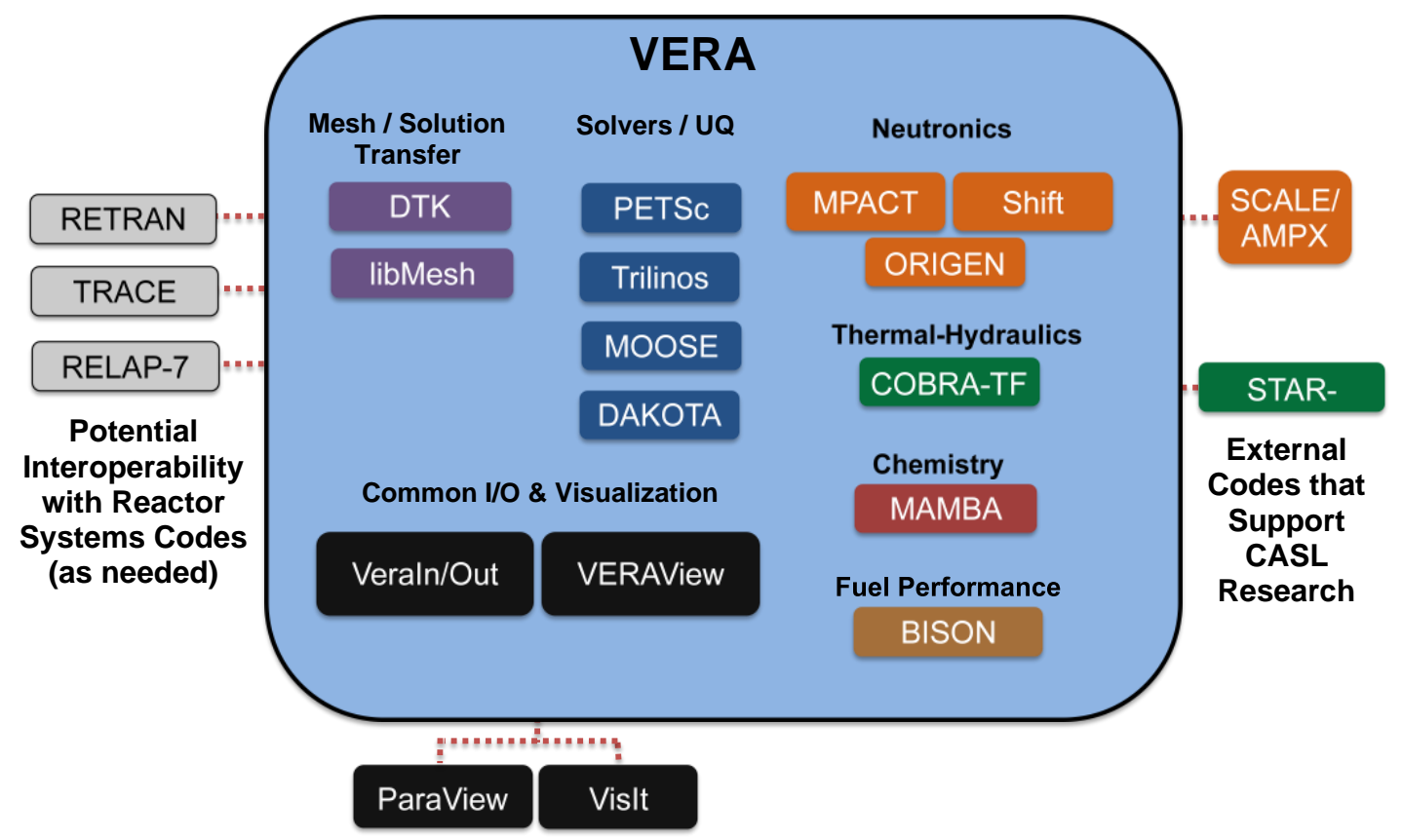

Figure 2. Virtual Environment for Reactor Applications (VERA).

The Shift Monte Carlo code is developed at ORNL and it is part of the Exnihilo code suite. It is a flexible, high-performance Monte Carlo radiation transport framework designed to scale from supercomputers to laptops. It has multiple front ends through the following:

1. Omnibus: fully featured general front-end

2. SCALE [14]: integrated into CSAS, TRITON and MAVRIC,

3. Insilico: integrated into VERA for in-core and ex-core analyses.

Shift is a physics-agnostic code, which means that it can run continuous energy (CE) or multigroup physics engines with SCALE. Shift is also geometry agnostic and has the ability to run on any of the following geometries through its Omnibus front end: Exnihilo RTK, MCNP [15], GG (KENO/SCALE), DAGMC CAD. Shift has fixed source and eigenvalue solvers. Research and development into state-of-the-art methods and algorithms has been performed and implemented within Shift. Shift is also capable of performing hybrid Monte Carlo / deterministic calculations for efficient calculations of deep penetration problems, and it can perform Monte Carlo depletion calculations. More recently, GPU implementation for CE physics with reactor geometry has been demonstrated with Shift.

The Serpent Monte Carlo code is developed by VTT Technical Research Centre of Finland, Ltd. It is a multipurpose 3D CE Monte Carlo code, and it can be run in parallel on HPCs. The applications for Serpent are divided into three categories [16]:

1. Reactor physics applications: spatial homogenization, criticality calculations, fuel cycle studies, research reactor modeling, and validation of deterministic transport codes 
2. Multi-physics simulations: coupled calculations with thermal hydraulics, CFD and fuel performance codes

3. Neutron and photon transport simulations for radiation dose rate calculations, shielding, fusion research and medical physics

Serpent uses surface tracking and Woodcock delta-tracking methods for particle transport, and it reads CE cross sections from ACE format libraries. Serpent can simulate explicit particle and pebble-bed fuel models for HTGR calculations. Serpent can import CAD and unstructured meshbased geometries. Serpent can also perform Monte Carlo depletion calculations, and two-way coupling to thermal-hydraulics, CFD, and fuel performance codes.

\section{INPUT PARAMETERS}

The inputs used in all the codes were kept consistent to enable consistency in the code-to-code comparisons and benchmarking. This section covers the geometry, materials, temperature, specific power, and densities used to set up the models for VERA, Shift, and Serpent.

\subsection{GEOMETRY AND DEPLETABLE REGIONS}

A 2D $17 \times 17$ PWR assembly was set up for all three codes. An MCNP model was set up to perform the Shift calculation. As mentioned earlier, Shift is geometry agnostic, and it can read MCNP geometry and perform Shift-based physics and depletion calculations with SCALE data using the MCNP geometry input format. The VERA, Serpent, and Shift models were set up consistently using the radii and pitch prescribed in Table $1[17,18]$. In all the three codes, each fuel pin is subdivided into three depletable regions of equal volumes, and the depleted isotopes are tracked within each of these cells. The radii of each of these subdivided depletable fuel regions are shown in Table 2 . There are 264 fuel pins which subsequently result in 792 depletable fuel regions that must be tracked. Figure 3 shows the depletable fuel regions in each pin cell marked with a red-hued cylinder, which is surrounded by ZIRLO clad in $\mathrm{UO}_{2}$ and an additional chromium coating for $\mathrm{U}_{3} \mathrm{Si}_{2}-\mathrm{BeO}, \mathrm{U}_{3} \mathrm{Si}_{2}-\mathrm{BeO}-$ $\mathrm{UB}_{2}, \mathrm{U}^{15} \mathrm{~N}-\mathrm{BeO}$, and $\mathrm{U}^{15} \mathrm{~N}-\mathrm{BeO}-\mathrm{UB}_{2}$ models. The fuel pin, lattice and assembly pitch dimensions, the guide tube dimensions, and the $\mathrm{UO}_{2}$ fuel and ZIRLO clad radii can be found in [17] and are presented here. The ATF fuel pin, ZIRLO clad and Cr coating dimensions are Westinghouseapproved dimensions for release obtained during this work [18].

Table 1. Geometry input parameters $[17,18]$

\begin{tabular}{|c|c|c|c|c|c|}
\hline $\begin{array}{l}\text { PWR } 17 \times 17 \text { geometry parameters } \\
(\mathrm{cm})\end{array}$ & $\mathbf{U O}_{2}$ & $\mathrm{U}_{3} \mathrm{Si}_{2}-\mathrm{BeO}$ & $\begin{array}{l}\mathrm{U}_{3} \mathrm{Si}_{2}-\mathrm{BeO}- \\
\mathrm{UB}_{2}\end{array}$ & $\mathrm{U}^{15} \mathrm{~N}-\mathrm{BeO}$ & $\begin{array}{l}\mathrm{U}^{15} \mathrm{~N}-\mathrm{BeO}- \\
\mathrm{UB}_{2}\end{array}$ \\
\hline Fuel radius & 0.409575 & 0.403860 & 0.403860 & 0.382333 & 0.382333 \\
\hline ZIRLO clad outer radius & 0.474980 & 0.468884 & 0.468884 & 0.447358 & 0.447358 \\
\hline Cr coating outer radius & - & 0.471384 & 0.471384 & 0.449858 & 0.449858 \\
\hline Fuel pin pitch & 1.25984 & 1.25984 & 1.25984 & 1.25984 & 1.25984 \\
\hline Guide tube inner radius & 0.56134 & 0.56134 & 0.56134 & 0.56134 & 0.56134 \\
\hline Guide tube outer radius & 0.601984 & 0.601984 & 0.601984 & 0.601984 & 0.601984 \\
\hline Lattice pitch & 21.41728 & 21.41728 & 21.41728 & 21.41728 & 21.41728 \\
\hline Assembly pitch & 21.50364 & 21.50364 & 21.50364 & 21.50364 & 21.50364 \\
\hline
\end{tabular}


Table 2. Radii of depletable regions

\begin{tabular}{|c|c|c|c|c|c|}
\hline $\begin{array}{c}\text { PWR } 17 \times 17 \text { geometry parameters } \\
(\mathrm{cm})\end{array}$ & $\mathbf{U O}_{2}$ & $\mathrm{U}_{3} \mathrm{Si}_{2}-\mathrm{BeO}$ & $\begin{array}{l}\mathrm{U}_{3} \mathrm{Si}_{2}-\mathrm{BeO}- \\
\mathrm{UB}_{2}\end{array}$ & $\mathbf{U}^{15} \mathbf{N}-\mathbf{B e O}$ & $\begin{array}{l}\mathrm{U}^{15} \mathrm{~N}-\mathrm{BeO}- \\
\mathrm{UB}_{2}\end{array}$ \\
\hline Fuel ring 1 radius & 0.236468 & 0.233169 & 0.233169 & 0.220740 & 0.220740 \\
\hline Fuel ring 2 radius & 0.334417 & 0.329750 & 0.329750 & 0.312174 & 0.312174 \\
\hline Fuel ring 3 radius & 0.409575 & 0.403860 & 0.403860 & 0.382333 & 0.382333 \\
\hline
\end{tabular}

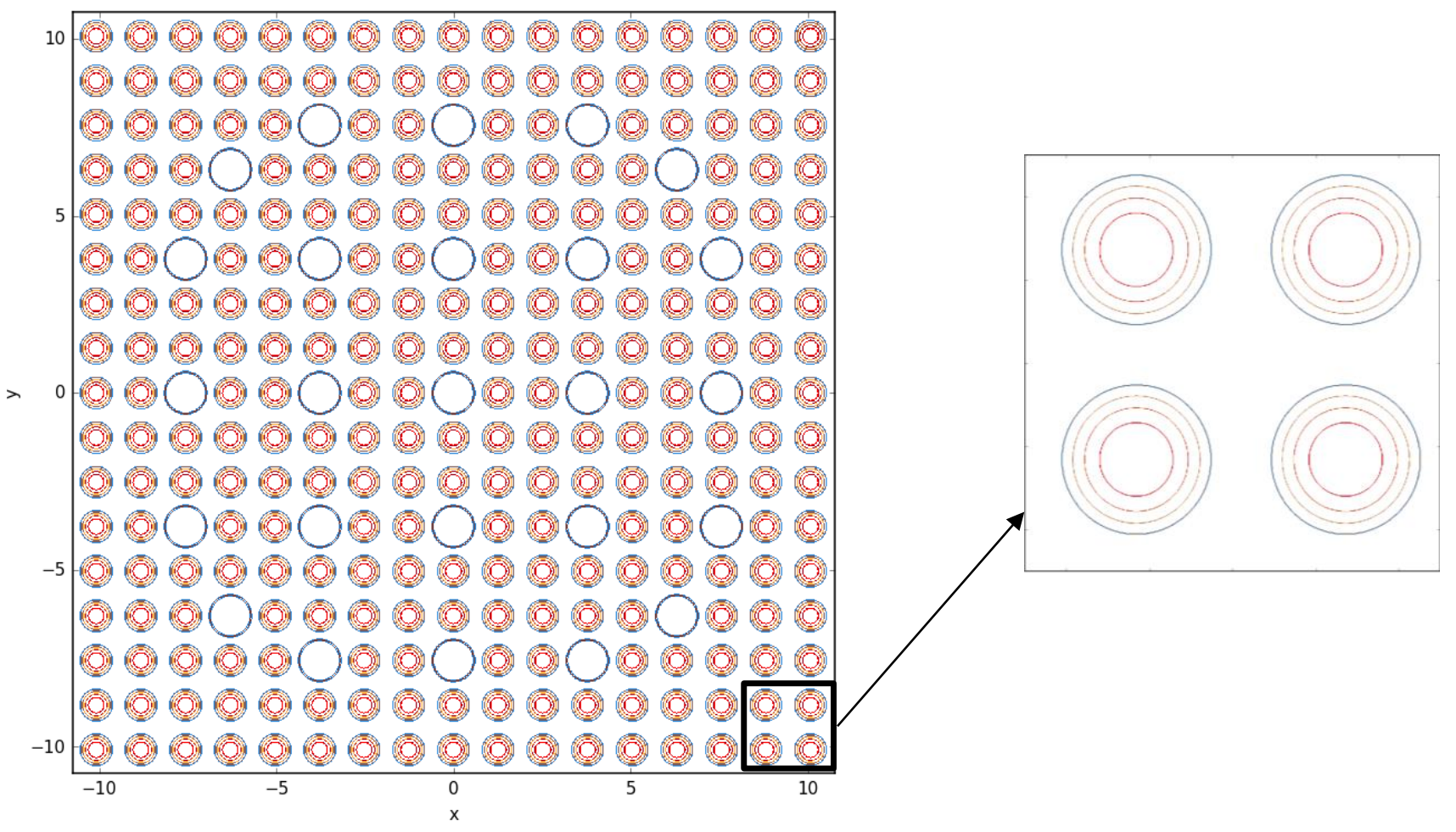

Figure 3. PWR lattice with three depletable fuel regions (zoomed in view of $2 \times 2$ pins). 


\subsection{MATERIAL}

The fuel material in each depletable region for five fuel types at the first time-step (zero burnup) is defined in Table 3. Table 4 shows non-fuel material compositions that are common to all the models: ZIRLO clad, Cr coating (if applicable), moderator, and ZIRLO guide tube.

Table 3. Fuel material compositions $[17,18]$

\begin{tabular}{|c|c|c|}
\hline Fuel & Isotope & Number density (atoms/b-cm) \\
\hline \multirow[t]{5}{*}{$\mathrm{UO}_{2}$} & 92234 & $1.0908303 \mathrm{E}-05$ \\
\hline & 92235 & $1.1490359 \mathrm{E}-03$ \\
\hline & 92236 & $3.3607102 \mathrm{E}-07$ \\
\hline & 92238 & $2.1774061 \mathrm{E}-02$ \\
\hline & 8016 & 4.5868683E-02 \\
\hline \multirow[t]{9}{*}{$\mathrm{U}_{3} \mathrm{Si}_{2}-\mathrm{BeO}$} & 92234 & $1.2333554 \mathrm{E}-05$ \\
\hline & 92235 & $1.2991660 \mathrm{E}-03$ \\
\hline & 92236 & $3.7998120 \mathrm{E}-07$ \\
\hline & 92238 & 2.4619004E-02 \\
\hline & 8016 & $3.4496489 \mathrm{E}-03$ \\
\hline & 14028 & $1.5913068 \mathrm{E}-02$ \\
\hline & 14029 & $8.0839619 \mathrm{E}-04$ \\
\hline & 14030 & $5.3352423 \mathrm{E}-04$ \\
\hline & 4009 & 3.4496489E-03 \\
\hline \multirow[t]{10}{*}{$\mathrm{U}_{3} \mathrm{Si}_{2}-\mathrm{BeO}-\mathrm{UB}_{2}$} & 92234 & $1.2334648 \mathrm{E}-05$ \\
\hline & 92235 & $1.2992813 \mathrm{E}-03$ \\
\hline & 92236 & 3.8001492E-07 \\
\hline & 92238 & $2.4621189 \mathrm{E}-02$ \\
\hline & 8016 & 3.4499025E-03 \\
\hline & 14028 & $1.5913068 \mathrm{E}-02$ \\
\hline & 14029 & $8.0839619 \mathrm{E}-04$ \\
\hline & 14030 & $5.3352423 \mathrm{E}-04$ \\
\hline & 4009 & 3.4499025E-03 \\
\hline & 5010 & $1.0140637 \mathrm{E}-04$ \\
\hline \multirow[t]{8}{*}{$\mathrm{U}^{15} \mathrm{~N}-\mathrm{BeO}$} & 92234 & $1.4644320 \mathrm{E}-05$ \\
\hline & 92235 & $1.5425727 \mathrm{E}-03$ \\
\hline & 92236 & 4.5117299E-07 \\
\hline & 92238 & $2.9231524 \mathrm{E}-02$ \\
\hline & 8016 & $3.6535150 \mathrm{E}-03$ \\
\hline & 7014 & 3.0789193E-04 \\
\hline & 7015 & $3.0481301 \mathrm{E}-02$ \\
\hline & 4009 & $3.6535150 \mathrm{E}-03$ \\
\hline \multirow[t]{9}{*}{$\mathrm{U}^{15} \mathrm{~N}-\mathrm{BeO}-\mathrm{UB}_{2}$} & 92234 & $1.4640966 \mathrm{E}-05$ \\
\hline & 92235 & $1.5422193 \mathrm{E}-03$ \\
\hline & 92236 & 4.5106965E-07 \\
\hline & 92238 & 2.9224829E-02 \\
\hline & 8016 & 3.6527297E-03 \\
\hline & 7014 & 3.0728433E-04 \\
\hline & 7015 & 3.0421149E-02 \\
\hline & 4009 & $3.6527297 \mathrm{E}-03$ \\
\hline & 5010 & $1.0741552 \mathrm{E}-04$ \\
\hline
\end{tabular}


Table 4. Non-fuel material compositions

\begin{tabular}{|c|c|c|}
\hline Common materials & Isotope & Number density (atoms/b-cm) \\
\hline \multirow[t]{21}{*}{ ZIRLO clad } & 8016 & $2.7100759 \mathrm{E}-04$ \\
\hline & 26054 & $3.9934579 \mathrm{E}-06$ \\
\hline & 26056 & $6.2688768 \mathrm{E}-05$ \\
\hline & 26057 & 1.4477573E-06 \\
\hline & 26058 & $1.9267001 \mathrm{E}-07$ \\
\hline & 40090 & $1.9125365 \mathrm{E}-02$ \\
\hline & 40091 & 4.1893667E-03 \\
\hline & 40092 & $6.3825560 \mathrm{E}-03$ \\
\hline & 40094 & $6.4420329 \mathrm{E}-03$ \\
\hline & 40096 & $1.0334030 \mathrm{E}-03$ \\
\hline & 41093 & $3.7336177 \mathrm{E}-04$ \\
\hline & 50112 & $2.8344530 \mathrm{E}-06$ \\
\hline & 50114 & $1.9286143 \mathrm{E}-06$ \\
\hline & 50115 & 9.9349173E-07 \\
\hline & 50116 & $4.2486366 \mathrm{E}-05$ \\
\hline & 50117 & $2.2441250 \mathrm{E}-05$ \\
\hline & 50118 & 7.0771782E-05 \\
\hline & 50119 & $2.5100285 \mathrm{E}-05$ \\
\hline & 50120 & $9.5199920 \mathrm{E}-05$ \\
\hline & 50122 & $1.3529034 \mathrm{E}-05$ \\
\hline & 50124 & 1.6918603E-05 \\
\hline \multirow[t]{4}{*}{ Chromium coating } & 24050 & $3.5980710 \mathrm{E}-03$ \\
\hline & 24052 & $6.9385218 \mathrm{E}-02$ \\
\hline & 24053 & 7.8677267E-03 \\
\hline & 24054 & $1.9584437 \mathrm{E}-03$ \\
\hline \multirow[t]{2}{*}{ Moderator } & 1001 & 4.7312447E-02 \\
\hline & 8016 & $2.3659884 \mathrm{E}-02$ \\
\hline \multirow[t]{21}{*}{ ZIRLO guide tube } & 8016 & $3.0728566 \mathrm{E}-04$ \\
\hline & 26054 & 4.5280367E-06 \\
\hline & 26056 & 7.1080515E-05 \\
\hline & 26057 & $1.6415594 \mathrm{E}-06$ \\
\hline & 26058 & $2.1846152 \mathrm{E}-07$ \\
\hline & 40090 & $2.1685556 \mathrm{E}-02$ \\
\hline & 40091 & 4.7501706E-03 \\
\hline & 40092 & 7.2369482E-03 \\
\hline & 40094 & 7.3043869E-03 \\
\hline & 40096 & $1.1717381 \mathrm{E}-03$ \\
\hline & 41093 & 4.2334134E-04 \\
\hline & 50112 & 3.2138833E-06 \\
\hline & 50114 & $2.1867856 \mathrm{E}-06$ \\
\hline & 50115 & $1.1264842 \mathrm{E}-06$ \\
\hline & 50116 & 4.8173746E-05 \\
\hline & 50117 & $2.5445318 \mathrm{E}-05$ \\
\hline & 50118 & $8.0245552 \mathrm{E}-05$ \\
\hline & 50119 & $2.8460301 \mathrm{E}-05$ \\
\hline & 50120 & $1.0794373 \mathrm{E}-04$ \\
\hline & 50122 & $1.5340080 \mathrm{E}-05$ \\
\hline & 50124 & $1.9183389 \mathrm{E}-05$ \\
\hline
\end{tabular}




\subsection{TEMPERATURE}

The temperatures of the materials in each region are provided in Table 5. All three codes used the ENDF/B-VII.1 [19, 20] library for the corresponding temperatures to perform the simulations documented in this report.

Table 5. Temperature of materials in each region

\begin{tabular}{|l|c|}
\hline \multicolumn{1}{|c|}{ Regions } & Temperature $(\mathbf{K})$ \\
\hline Fuel & 900 \\
\hline ZIRLO clad & 600 \\
\hline Cr coating & 600 \\
\hline Moderator & 600 \\
\hline Guide tube & 600 \\
\hline
\end{tabular}

\subsection{SPECIFIC POWER AND DENSITY}

The specific powers and densities of the fuels were obtained from CASL's Westinghouse collaborators, as listed in Table 6. These values were kept consistent between all three codes for all models.

Table 6. Specific power and density of materials in each region

\begin{tabular}{|l|c|c|c|}
\hline \multicolumn{1}{|c|}{ Fuel } & Specific Power $(\mathbf{W} / \mathrm{gU})$ & Fuel Density $\left(\mathrm{g} / \mathrm{cm}^{3}\right)$ & U Density $\left(\mathrm{g} / \mathrm{cm}^{3}\right)$ \\
\hline $\mathrm{UO}_{2}$ & 40.311 & 10.27825 & 9.05997 \\
\hline $\mathrm{U}_{3} \mathrm{Si}_{2}-\mathrm{BeO}$ & 36.669 & 11.19169 & 10.24372 \\
\hline $\mathrm{U}_{3} \mathrm{Si}_{2}-\mathrm{BeO}-\mathrm{UB}_{2}$ & 36.666 & 11.19429 & 10.24463 \\
\hline $\mathrm{U}^{15} \mathrm{~N}-\mathrm{BeO}$ & 34.458 & 13.08105 & 12.16294 \\
\hline $\mathrm{U}^{15} \mathrm{~N}-\mathrm{BeO}-\mathrm{UB}_{2}$ & 34.466 & 13.07850 & 12.16015 \\
\hline
\end{tabular}

\section{RESULTS}

Various depletion methods and parameters can be defined in each code to perform depletion calculations. VERA uses a predictor-corrector approach and tracks the depletion and decay of 263 isotopes during a depletion calculation. For this benchmark exercise, Serpent calculations were executed with the predictor-corrector method and with a user-defined fission product yield cutoff of $1 \times 10^{-6}$ to track isotopes of fission yields greater than this user-defined value. Shift depletion calculations were performed using the fully explicit method (set as default), which tracks all 2,200 isotopes available within the ORIGEN library in each depletable region. For the Shift calculations, the flux is renormalized at each substep based on the energy released during the depletion.

At the first time (zero burnup) for the standard $\mathrm{UO}_{2}$ lattice, VERA agrees well with Serpent, with less than 100 pcm difference in keff, whereas Shift and VERA differ by $168 \mathrm{pcm}$. For $\mathrm{U}_{3} \mathrm{Si}_{2}-\mathrm{BeO}$ fuel, VERA and Serpent keff differ by 201 pcm, while Shift and VERA differ by 300 pcm, and for $\mathrm{U}^{15} \mathrm{~N}-\mathrm{BeO}$ fuel, VERA and Serpent results differ by $238 \mathrm{pcm}$, whereas Shift and VERA results differ by $348 \mathrm{pcm}$. VERA and Serpent are in closer agreement for cases with $\mathrm{UB}_{2}$ than Shift and VERA. For $\mathrm{U}_{3} \mathrm{Si}_{2}-\mathrm{BeO}-\mathrm{UB}_{2}$ fuel, VERA and Serpent $\mathrm{k}_{\text {eff }}$ differ by $100 \mathrm{pcm}$, while Shift and VERA differ by $317 \mathrm{pcm}$, and for $\mathrm{U}^{15} \mathrm{~N}-\mathrm{BeO}-\mathrm{UB}_{2}$ fuel, VERA and Serpent results differ by $158 \mathrm{pcm}$, whereas Shift and VERA results differ by $340 \mathrm{pcm}$. 
There are notable differences between VERA and the Monte Carlo codes, Serpent and Shift, at the first time-step. However, these differences are larger between VERA and Shift. Figure 4 shows the differences between VERA and Serpent and between VERA and Shift for each of the cases analyzed for this benchmark study. Recent changes to the thermal scattering data limit in Shift could be a root cause of differences seen between VERA and Shift, although this needs to be investigated further. To narrow in on the cause of the differences between VERA and Shift, fuel pin depletion calculations must be performed for each fuel type. This benchmark document will be revised with current findings after these pin calculations are performed. Prior depletion benchmarking efforts between VERA and Shift have shown closer agreement for $\mathrm{UO}_{2}$ [21].

Figure 5 shows the differences between Shift and Serpent Monte Carlo codes. For non-UB $\mathrm{U}_{2}$ fuel cases, Shift and Serpent are in good agreement, especially at lower burnup. As the burnup increases, Shift has a more negative keff than Serpent, possibly due to the tracking and buildup of 2,200 nuclides that might be more significant at higher burnup. However, for fuel with UB2, Shift and Serpent differ by $\sim 200$ pcm at zero burnup. Sections 5.1-5.5 show the keff at each time step for all the codes, and Section 5.6 shows the difference between Shift and Serpent results.

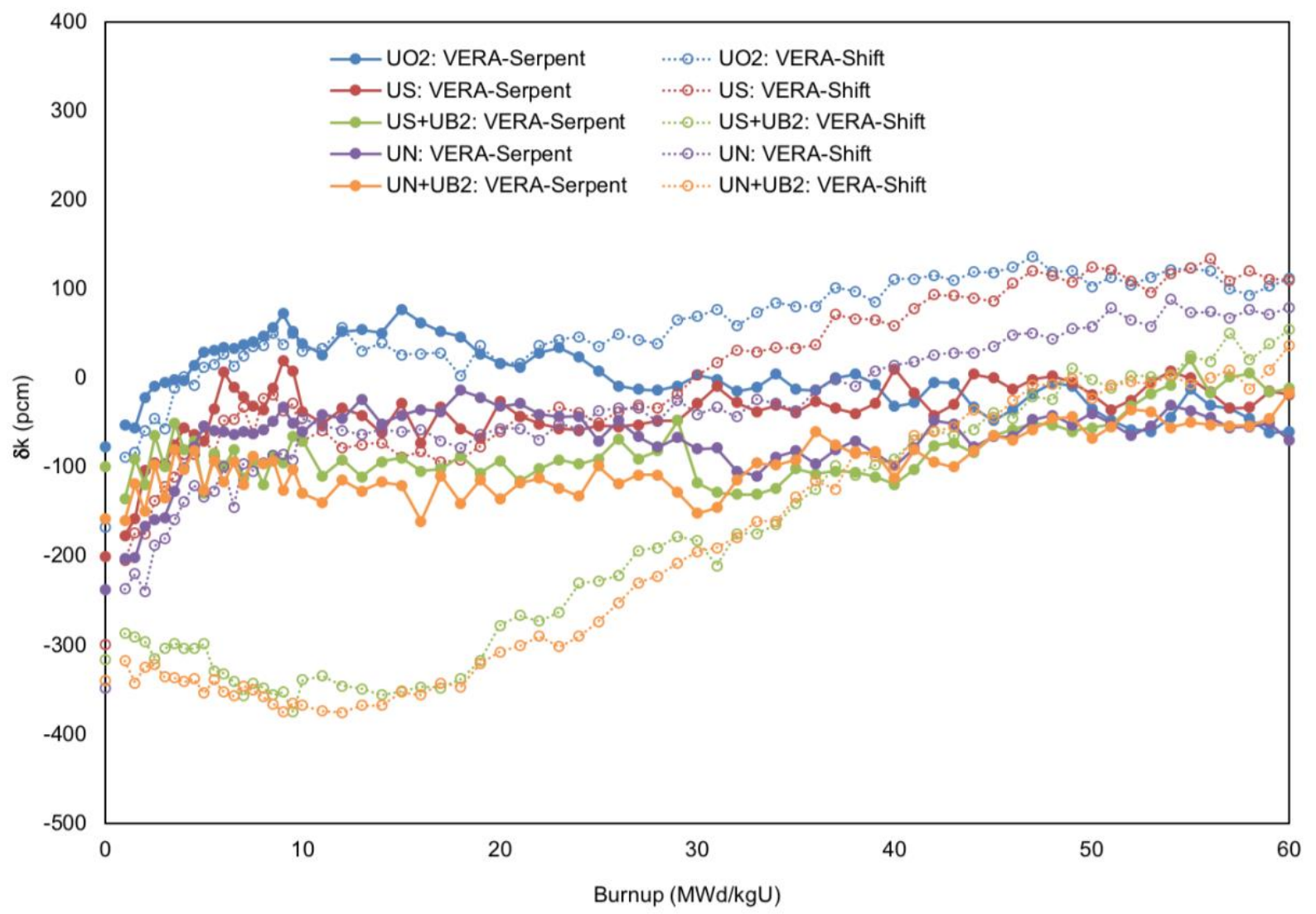

Figure 4. PWR lattice with three depletable fuel regions. 


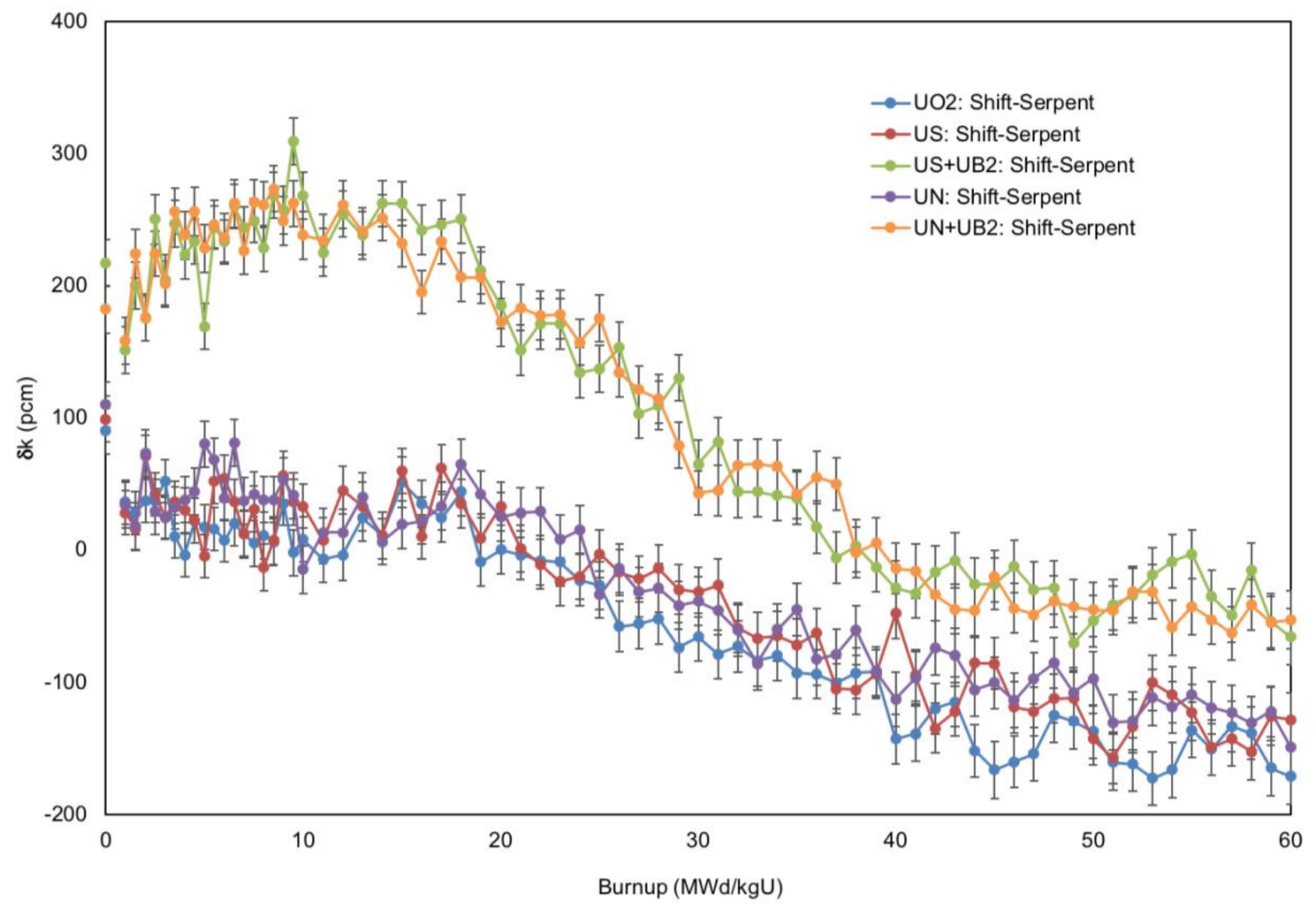

Figure 5. Differences between Shift and Serpent results.

\section{1. $\mathrm{UO}_{2}$}

Table 7. Comparison of $2 \mathrm{D} 17 \times 17 \mathrm{UO}_{2}$ results

\begin{tabular}{|c|c|c|c|c|c|c|c|c|c|}
\hline \multirow{2}{*}{$\begin{array}{c}\text { BU } \\
(\mathbf{M W d} / \mathbf{k g U})\end{array}$} & \multirow{2}{*}{$\frac{\text { VERA }}{k_{\text {eff }}}$} & \multicolumn{2}{|c|}{ Serpent } & \multicolumn{2}{|c|}{ Shift } & \multicolumn{2}{|c|}{$\begin{array}{c}\text { Difference } \\
\text { (VERA - Serpent) }\end{array}$} & \multicolumn{2}{|c|}{$\begin{array}{c}\text { Difference } \\
\text { (VERA - Shift) } \\
\end{array}$} \\
\hline & & $\mathbf{k}_{\text {eff }}$ & $\begin{array}{c}1 \sigma \text { std. } \\
\text { dev. }\end{array}$ & $\mathbf{k}_{\mathrm{eff}}$ & $\begin{array}{c}1 \sigma \text { std. } \\
\text { dev. }\end{array}$ & $\delta \mathbf{k}_{\text {eff }}$ & $\begin{array}{l}\text { 16 std. } \\
\text { dev. }\end{array}$ & $\delta \mathbf{k}_{\text {eff }}$ & 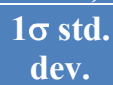 \\
\hline 0 & 1.42718 & 1.42796 & 12 & 1.42886 & 13 & -78 & 12 & -168 & 13 \\
\hline 1 & 1.36315 & 1.36368 & 12 & 1.36404 & 12 & -53 & 12 & -89 & 12 \\
\hline 1.5 & 1.35758 & 1.35814 & 11 & 1.35842 & 12 & -56 & 11 & -84 & 12 \\
\hline 2 & 1.35238 & 1.35260 & 11 & 1.35297 & 12 & -22 & 11 & -59 & 12 \\
\hline 2.5 & 1.34717 & 1.34726 & 11 & 1.34763 & 12 & -9 & 11 & -46 & 12 \\
\hline 3 & 1.34187 & 1.34192 & 11 & 1.34244 & 12 & -5 & 11 & -57 & 12 \\
\hline 3.5 & 1.33649 & 1.33651 & 11 & 1.33661 & 12 & -2 & 11 & -12 & 12 \\
\hline 4 & 1.33106 & 1.33109 & 12 & 1.33105 & 11 & -3 & 12 & 1 & 11 \\
\hline 4.5 & 1.32560 & 1.32546 & 12 & 1.32568 & 12 & 14 & 12 & -8 & 12 \\
\hline 5 & 1.32013 & 1.31984 & 12 & 1.32001 & 12 & 29 & 12 & 12 & 12 \\
\hline 5.5 & 1.31467 & 1.31436 & 11 & 1.31452 & 12 & 31 & 11 & 15 & 12 \\
\hline 6 & 1.30923 & 1.30889 & 11 & 1.30896 & 11 & 34 & 11 & 27 & 11 \\
\hline 6.5 & 1.30382 & 1.30349 & 12 & 1.30369 & 12 & 33 & 12 & 13 & 12 \\
\hline 7 & 1.29845 & 1.29808 & 13 & 1.29820 & 12 & 37 & 13 & 25 & 12 \\
\hline 7.5 & 1.29313 & 1.29273 & 13 & 1.29278 & 12 & 40 & 13 & 35 & 12 \\
\hline
\end{tabular}




\begin{tabular}{|c|c|c|c|c|c|c|c|c|c|}
\hline \multirow{2}{*}{$\begin{array}{c}\text { BU } \\
(\mathbf{M W d} / \mathbf{k g U})\end{array}$} & \multirow{2}{*}{$\frac{\text { VERA }}{\mathbf{k}_{\mathrm{eff}}}$} & \multicolumn{2}{|c|}{ Serpent } & \multicolumn{2}{|c|}{ Shift } & \multicolumn{2}{|c|}{$\begin{array}{c}\text { Difference } \\
\text { (VERA - Serpent) }\end{array}$} & \multicolumn{2}{|c|}{$\begin{array}{c}\text { Difference } \\
\text { (VERA - Shift) } \\
\end{array}$} \\
\hline & & $\mathbf{k}_{\mathrm{eff}}$ & $\begin{array}{c}1 \sigma \text { std. } \\
\text { dev. }\end{array}$ & $\mathbf{k}_{\text {eff }}$ & $\begin{array}{c}1 \sigma \text { std. } \\
\text { dev. }\end{array}$ & $\delta \mathbf{k}_{\text {eff }}$ & $\begin{array}{c}1 \sigma \text { std. } \\
\text { dev. }\end{array}$ & $\delta \mathbf{k}_{\text {eff }}$ & 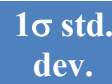 \\
\hline 8 & 1.28785 & 1.28738 & 13 & 1.28749 & 12 & 47 & 13 & 36 & 12 \\
\hline 8.5 & 1.28263 & 1.28207 & 13 & 1.28213 & 12 & 56 & 13 & 50 & 12 \\
\hline 9 & 1.27747 & 1.27675 & 12 & 1.27710 & 11 & 72 & 12 & 37 & 11 \\
\hline 9.5 & 1.27237 & 1.27187 & 13 & 1.27185 & 11 & 50 & 13 & 52 & 11 \\
\hline 10 & 1.26737 & 1.26699 & 13 & 1.26707 & 11 & 38 & 13 & 30 & 11 \\
\hline 11 & 1.25748 & 1.25722 & 13 & 1.25715 & 12 & 26 & 13 & 33 & 12 \\
\hline 12 & 1.24780 & 1.24728 & 15 & 1.24724 & 12 & 52 & 15 & 56 & 12 \\
\hline 13 & 1.23834 & 1.23780 & 13 & 1.23804 & 11 & 54 & 13 & 30 & 11 \\
\hline 14 & 1.22909 & 1.22859 & 14 & 1.22870 & 11 & 50 & 14 & 39 & 11 \\
\hline 15 & 1.22004 & 1.21927 & 15 & 1.21978 & 12 & 77 & 15 & 26 & 12 \\
\hline 16 & 1.21117 & 1.21055 & 14 & 1.21090 & 11 & 62 & 14 & 27 & 11 \\
\hline 17 & 1.20247 & 1.20195 & 14 & 1.20219 & 12 & 52 & 14 & 28 & 12 \\
\hline 18 & 1.19393 & 1.19347 & 15 & 1.19391 & 11 & 46 & 15 & 2 & 11 \\
\hline 19 & 1.18553 & 1.18526 & 14 & 1.18517 & 12 & 27 & 14 & 36 & 12 \\
\hline 20 & 1.17731 & 1.17715 & 15 & 1.17715 & 11 & 16 & 15 & 16 & 11 \\
\hline 21 & 1.16917 & 1.16905 & 15 & 1.16901 & 11 & 12 & 15 & 16 & 11 \\
\hline 22 & 1.16115 & 1.16087 & 15 & 1.16079 & 11 & 28 & 15 & 36 & 11 \\
\hline 23 & 1.15323 & 1.15289 & 15 & 1.15280 & 11 & 34 & 15 & 43 & 11 \\
\hline 24 & 1.14540 & 1.14517 & 16 & 1.14494 & 11 & 23 & 16 & 46 & 11 \\
\hline 25 & 1.13767 & 1.13759 & 15 & 1.13732 & 10 & 8 & 15 & 35 & 10 \\
\hline 26 & 1.13001 & 1.13010 & 16 & 1.12952 & 10 & -9 & 16 & 49 & 10 \\
\hline 27 & 1.12244 & 1.12257 & 16 & 1.12201 & 11 & -13 & 16 & 43 & 11 \\
\hline 28 & 1.11493 & 1.11507 & 16 & 1.11455 & 11 & -14 & 16 & 38 & 11 \\
\hline 29 & 1.10750 & 1.10759 & 15 & 1.10685 & 11 & -9 & 15 & 65 & 11 \\
\hline 30 & 1.10009 & 1.10006 & 15 & 1.09940 & 10 & 3 & 15 & 69 & 10 \\
\hline 31 & 1.09278 & 1.09280 & 15 & 1.09201 & 10 & -2 & 15 & 77 & 10 \\
\hline 32 & 1.08553 & 1.08568 & 16 & 1.08495 & 11 & -15 & 16 & 58 & 11 \\
\hline 33 & 1.07833 & 1.07844 & 16 & 1.07760 & 10 & -11 & 16 & 73 & 10 \\
\hline 34 & 1.07119 & 1.07115 & 16 & 1.07035 & 10 & 4 & 16 & 84 & 10 \\
\hline 35 & 1.06410 & 1.06423 & 16 & 1.06330 & 11 & -13 & 16 & 80 & 11 \\
\hline 36 & 1.05706 & 1.05720 & 15 & 1.05626 & 10 & -14 & 15 & 80 & 10 \\
\hline 37 & 1.05008 & 1.05008 & 16 & 1.04907 & 11 & 0 & 16 & 101 & 11 \\
\hline 38 & 1.04314 & 1.04310 & 16 & 1.04217 & 10 & 4 & 16 & 97 & 10 \\
\hline 39 & 1.03625 & 1.03632 & 15 & 1.03540 & 10 & -7 & 15 & 85 & 10 \\
\hline 40 & 1.02934 & 1.02966 & 16 & 1.02823 & 10 & -32 & 16 & 111 & 10 \\
\hline 41 & 1.02255 & 1.02283 & 18 & 1.02144 & 10 & -28 & 18 & 111 & 10 \\
\hline 42 & 1.01581 & 1.01586 & 17 & 1.01466 & 9 & -5 & 17 & 115 & 9 \\
\hline 43 & 1.00912 & 1.00918 & 16 & 1.00803 & 9 & -6 & 16 & 109 & 9 \\
\hline 44 & 1.00249 & 1.00282 & 17 & 1.00130 & 10 & -33 & 17 & 119 & 10 \\
\hline 45 & 0.99591 & 0.99639 & 19 & 0.99473 & 10 & -48 & 19 & 118 & 10 \\
\hline 46 & 0.98938 & 0.98974 & 17 & 0.98814 & 10 & -36 & 17 & 124 & 10 \\
\hline
\end{tabular}




\begin{tabular}{|c|c|c|c|c|c|c|c|c|c|}
\hline \multirow{2}{*}{$\begin{array}{c}\text { BU } \\
(\mathbf{M W d} / \mathbf{k g U})\end{array}$} & \multirow{2}{*}{$\frac{\text { VERA }}{\mathbf{k}_{\mathrm{eff}}}$} & \multicolumn{2}{|c|}{ Serpent } & \multicolumn{2}{|c|}{ Shift } & \multicolumn{2}{|c|}{$\begin{array}{c}\text { Difference } \\
\text { (VERA - Serpent) }\end{array}$} & \multicolumn{2}{|c|}{$\begin{array}{c}\text { Difference } \\
\text { (VERA - Shift) } \\
\end{array}$} \\
\hline & & $k_{\text {eff }}$ & $\begin{array}{c}1 \sigma \text { std. } \\
\text { dev. }\end{array}$ & $\mathbf{k}_{\mathrm{eff}}$ & $\begin{array}{c}1 \sigma \text { std. } \\
\text { dev. }\end{array}$ & $\delta \mathbf{k}_{\text {eff }}$ & 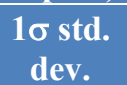 & $\delta k_{\text {eff }}$ & 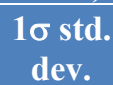 \\
\hline 47 & 0.98291 & 0.98309 & 18 & 0.98155 & 9 & -18 & 18 & 136 & 9 \\
\hline 48 & 0.97650 & 0.97656 & 18 & 0.97531 & 10 & -6 & 18 & 119 & 10 \\
\hline 49 & 0.97015 & 0.97024 & 19 & 0.96894 & 9 & -9 & 19 & 121 & 9 \\
\hline 50 & 0.96379 & 0.96414 & 18 & 0.96277 & 10 & -35 & 18 & 103 & 10 \\
\hline 51 & 0.95756 & 0.95804 & 19 & 0.95643 & 10 & -48 & 19 & 113 & 10 \\
\hline 52 & 0.95141 & 0.95199 & 18 & 0.95037 & 9 & -58 & 18 & 104 & 9 \\
\hline 53 & 0.94531 & 0.94591 & 18 & 0.94418 & 9 & -60 & 18 & 113 & 9 \\
\hline 54 & 0.93929 & 0.93974 & 19 & 0.93808 & 9 & -45 & 19 & 121 & 9 \\
\hline 55 & 0.93334 & 0.93347 & 19 & 0.93211 & 9 & -13 & 19 & 123 & 9 \\
\hline 56 & 0.92747 & 0.92778 & 17 & 0.92627 & 9 & -31 & 17 & 120 & 9 \\
\hline 57 & 0.92167 & 0.92201 & 17 & 0.92068 & 9 & -34 & 17 & 99 & 9 \\
\hline 58 & 0.91595 & 0.91641 & 18 & 0.91502 & 9 & -46 & 18 & 93 & 9 \\
\hline 59 & 0.91032 & 0.91094 & 19 & 0.90929 & 9 & -62 & 19 & 103 & 9 \\
\hline 60 & 0.90471 & 0.90531 & 19 & 0.90360 & 9 & -60 & 19 & 111 & 9 \\
\hline
\end{tabular}

\section{2. $\mathrm{U}_{3} \mathrm{Si}_{2}-\mathrm{BeO}$}

Table 8. Comparison of $2 \mathrm{D} 17 \times 17 \mathrm{U}_{3} \mathrm{Si}_{2}-\mathrm{BeO}$ results

\begin{tabular}{|c|c|c|c|c|c|c|c|c|c|}
\hline \multirow{2}{*}{$\begin{array}{c}\text { BU } \\
(\mathbf{M W d} / \mathrm{kgU})\end{array}$} & \multirow{2}{*}{$\frac{\text { VERA }}{\mathrm{k}_{\mathrm{eff}}}$} & \multicolumn{2}{|c|}{ Serpent } & \multicolumn{2}{|c|}{ Shift } & \multicolumn{2}{|c|}{$\begin{array}{c}\text { Difference } \\
\text { (VERA - Serpent) }\end{array}$} & \multicolumn{2}{|c|}{$\begin{array}{c}\text { Difference } \\
\text { (VERA - Shift) }\end{array}$} \\
\hline & & $\mathbf{k}_{\text {eff }}$ & $\begin{array}{l}1 \sigma \text { std. } \\
\text { dev. }\end{array}$ & $\mathbf{k}_{\text {eff }}$ & $\begin{array}{l}1 \sigma \text { std. } \\
\text { dev. }\end{array}$ & $\delta \mathbf{k}_{\text {eff }}$ & $\begin{array}{l}1 \sigma \text { std. } \\
\text { dev. }\end{array}$ & $\delta k_{\text {eff }}$ & $\begin{array}{l}1 \sigma \text { std. } \\
\text { dev. }\end{array}$ \\
\hline 0 & 1.41893 & 1.42094 & 12 & 1.42193 & 12 & -201 & 12 & -300 & 12 \\
\hline 1 & 1.35727 & 1.35904 & 11 & 1.35932 & 12 & -177 & 11 & -205 & 12 \\
\hline 1.5 & 1.35161 & 1.35319 & 11 & 1.35335 & 12 & -158 & 11 & -174 & 12 \\
\hline 2 & 1.34631 & 1.34735 & 11 & 1.34806 & 11 & -104 & 11 & -175 & 11 \\
\hline 2.5 & 1.34099 & 1.34195 & 11 & 1.34237 & 12 & -96 & 11 & -138 & 12 \\
\hline 3 & 1.33559 & 1.33656 & 11 & 1.33681 & 12 & -97 & 11 & -122 & 12 \\
\hline 3.5 & 1.33012 & 1.33087 & 11 & 1.33123 & 12 & -75 & 11 & -111 & 12 \\
\hline 4 & 1.32461 & 1.32517 & 12 & 1.32547 & 12 & -56 & 12 & -86 & 12 \\
\hline 4.5 & 1.31907 & 1.31971 & 12 & 1.31993 & 12 & -64 & 12 & -86 & 12 \\
\hline 5 & 1.31354 & 1.31425 & 12 & 1.31420 & 11 & -71 & 12 & -66 & 11 \\
\hline 5.5 & 1.30802 & 1.30837 & 13 & 1.30889 & 11 & -35 & 13 & -87 & 11 \\
\hline 6 & 1.30254 & 1.30248 & 13 & 1.30302 & 12 & 6 & 13 & -48 & 12 \\
\hline 6.5 & 1.29709 & 1.29720 & 13 & 1.29756 & 11 & -11 & 13 & -47 & 11 \\
\hline 7 & 1.29170 & 1.29191 & 12 & 1.29203 & 12 & -21 & 12 & -33 & 12 \\
\hline 7.5 & 1.28636 & 1.28668 & 13 & 1.28699 & 11 & -32 & 13 & -63 & 11 \\
\hline 8 & 1.28108 & 1.28144 & 13 & 1.28131 & 12 & -36 & 13 & -23 & 12 \\
\hline 8.5 & 1.27586 & 1.27598 & 14 & 1.27605 & 12 & -12 & 14 & -19 & 12 \\
\hline 9 & 1.27070 & 1.27051 & 15 & 1.27107 & 11 & 19 & 15 & -37 & 11 \\
\hline 9.5 & 1.26561 & 1.26554 & 13 & 1.26590 & 11 & 7 & 13 & -29 & 11 \\
\hline
\end{tabular}




\begin{tabular}{|c|c|c|c|c|c|c|c|c|c|}
\hline \multirow{2}{*}{$\begin{array}{c}\text { BU } \\
(\mathrm{MWd} / \mathrm{kgU})\end{array}$} & \multirow{2}{*}{$\frac{\text { VERA }}{\mathbf{k}_{\mathrm{eff}}}$} & \multicolumn{2}{|c|}{ Serpent } & \multicolumn{2}{|c|}{ Shift } & \multicolumn{2}{|c|}{$\begin{array}{c}\text { Difference } \\
\text { (VERA - Serpent) }\end{array}$} & \multicolumn{2}{|c|}{$\begin{array}{c}\text { Difference } \\
\text { (VERA - Shift) } \\
\end{array}$} \\
\hline & & $\mathbf{k}_{\mathrm{eff}}$ & $\begin{array}{l}1 \sigma \text { std. } \\
\text { dev. }\end{array}$ & $\mathbf{k}_{\text {eff }}$ & $\begin{array}{c}1 \sigma \text { std. } \\
\text { dev. }\end{array}$ & $\delta \mathbf{k}_{\text {eff }}$ & $\begin{array}{c}1 \sigma \text { std. } \\
\text { dev. }\end{array}$ & $\delta \mathbf{k}_{\text {eff }}$ & 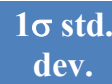 \\
\hline 10 & 1.26019 & 1.26057 & 12 & 1.26090 & 12 & -38 & 12 & -71 & 12 \\
\hline 11 & 1.25031 & 1.25083 & 13 & 1.25090 & 12 & -52 & 13 & -59 & 12 \\
\hline 12 & 1.24065 & 1.24099 & 14 & 1.24144 & 11 & -34 & 14 & -79 & 11 \\
\hline 13 & 1.23122 & 1.23164 & 14 & 1.23197 & 12 & -42 & 14 & -75 & 12 \\
\hline 14 & 1.22202 & 1.22264 & 14 & 1.22275 & 11 & -62 & 14 & -73 & 11 \\
\hline 15 & 1.21301 & 1.21330 & 13 & 1.21390 & 11 & -29 & 13 & -89 & 11 \\
\hline 16 & 1.20419 & 1.20492 & 13 & 1.20502 & 11 & -73 & 13 & -83 & 11 \\
\hline 17 & 1.19554 & 1.19587 & 14 & 1.19649 & 11 & -33 & 14 & -95 & 11 \\
\hline 18 & 1.18704 & 1.18761 & 14 & 1.18796 & 12 & -57 & 14 & -92 & 12 \\
\hline 19 & 1.17869 & 1.17937 & 14 & 1.17946 & 11 & -68 & 14 & -77 & 11 \\
\hline 20 & 1.17068 & 1.17095 & 15 & 1.17128 & 11 & -27 & 15 & -60 & 11 \\
\hline 21 & 1.16261 & 1.16304 & 14 & 1.16305 & 11 & -43 & 14 & -44 & 11 \\
\hline 22 & 1.15464 & 1.15516 & 15 & 1.15505 & 11 & -52 & 15 & -41 & 11 \\
\hline 23 & 1.14677 & 1.14734 & 15 & 1.14710 & 10 & -57 & 15 & -33 & 10 \\
\hline 24 & 1.13900 & 1.13959 & 14 & 1.13939 & 10 & -59 & 14 & -39 & 10 \\
\hline 25 & 1.13132 & 1.13186 & 15 & 1.13183 & 10 & -54 & 15 & -51 & 10 \\
\hline 26 & 1.12373 & 1.12428 & 14 & 1.12411 & 10 & -55 & 14 & -38 & 10 \\
\hline 27 & 1.11620 & 1.11673 & 14 & 1.11651 & 10 & -53 & 14 & -31 & 10 \\
\hline 28 & 1.10876 & 1.10924 & 14 & 1.10910 & 11 & -48 & 14 & -34 & 11 \\
\hline 29 & 1.10138 & 1.10186 & 15 & 1.10156 & 11 & -48 & 15 & -18 & 11 \\
\hline 30 & 1.09432 & 1.09461 & 16 & 1.09429 & 10 & -29 & 16 & 3 & 10 \\
\hline 31 & 1.08709 & 1.08719 & 17 & 1.08692 & 11 & -10 & 17 & 17 & 11 \\
\hline 32 & 1.07991 & 1.08019 & 16 & 1.07960 & 10 & -28 & 16 & 31 & 10 \\
\hline 33 & 1.07279 & 1.07317 & 16 & 1.07250 & 11 & -38 & 16 & 29 & 11 \\
\hline 34 & 1.06572 & 1.06603 & 16 & 1.06538 & 10 & -31 & 16 & 34 & 10 \\
\hline 35 & 1.05871 & 1.05910 & 17 & 1.05838 & 10 & -39 & 17 & 33 & 10 \\
\hline 36 & 1.05176 & 1.05202 & 16 & 1.05139 & 10 & -26 & 16 & 37 & 10 \\
\hline 37 & 1.04486 & 1.04520 & 16 & 1.04415 & 10 & -34 & 16 & 71 & 10 \\
\hline 38 & 1.03801 & 1.03841 & 16 & 1.03735 & 10 & -40 & 16 & 66 & 10 \\
\hline 39 & 1.03121 & 1.03150 & 16 & 1.03056 & 10 & -29 & 16 & 65 & 10 \\
\hline 40 & 1.02453 & 1.02443 & 16 & 1.02395 & 10 & 10 & 16 & 58 & 10 \\
\hline 41 & 1.01785 & 1.01802 & 17 & 1.01707 & 9 & -17 & 17 & 78 & 9 \\
\hline 42 & 1.01122 & 1.01164 & 16 & 1.01029 & 10 & -42 & 16 & 93 & 10 \\
\hline 43 & 1.00465 & 1.00495 & 16 & 1.00373 & 10 & -30 & 16 & 92 & 10 \\
\hline 44 & 0.99813 & 0.99809 & 17 & 0.99723 & 10 & 4 & 17 & 90 & 10 \\
\hline 45 & 0.99167 & 0.99167 & 17 & 0.99081 & 10 & 0 & 17 & 86 & 10 \\
\hline 46 & 0.98527 & 0.98540 & 17 & 0.98421 & 9 & -13 & 17 & 106 & 9 \\
\hline 47 & 0.97893 & 0.97895 & 16 & 0.97773 & 10 & -2 & 16 & 120 & 10 \\
\hline 48 & 0.97265 & 0.97263 & 16 & 0.97151 & 9 & 2 & 16 & 115 & 9 \\
\hline 49 & 0.96644 & 0.96649 & 17 & 0.96537 & 10 & -5 & 17 & 107 & 10 \\
\hline 50 & 0.96019 & 0.96038 & 17 & 0.95895 & 10 & -19 & 17 & 124 & 10 \\
\hline
\end{tabular}




\begin{tabular}{|c|c|c|c|c|c|c|c|c|c|}
\hline \multirow{2}{*}{$\begin{array}{c}\text { BU } \\
(\mathrm{MWd} / \mathrm{kgU})\end{array}$} & \multirow{2}{*}{$\frac{\text { VERA }}{\mathbf{k}_{\mathrm{eff}}}$} & \multicolumn{2}{|c|}{ Serpent } & \multicolumn{2}{|c|}{ Shift } & \multicolumn{2}{|c|}{$\begin{array}{c}\text { Difference } \\
\text { (VERA - Serpent) }\end{array}$} & \multicolumn{2}{|c|}{$\begin{array}{c}\text { Difference } \\
\text { (VERA - Shift) } \\
\end{array}$} \\
\hline & & $k_{\text {eff }}$ & $\begin{array}{c}1 \sigma \text { std. } \\
\text { dev. }\end{array}$ & $k_{\text {eff }}$ & $\begin{array}{c}1 \sigma \text { std. } \\
\text { dev. }\end{array}$ & $\delta \mathbf{k}_{\text {eff }}$ & 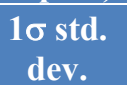 & $\delta \mathbf{k}_{\text {eff }}$ & 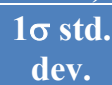 \\
\hline 51 & 0.95411 & 0.95447 & 17 & 0.95290 & 9 & -36 & 17 & 121 & 9 \\
\hline 52 & 0.94810 & 0.94835 & 18 & 0.94702 & 9 & -25 & 18 & 108 & 9 \\
\hline 53 & 0.94216 & 0.94221 & 19 & 0.94121 & 9 & -5 & 19 & 96 & 9 \\
\hline 54 & 0.93630 & 0.93623 & 19 & 0.93513 & 10 & 7 & 19 & 117 & 10 \\
\hline 55 & 0.93051 & 0.93051 & 19 & 0.92928 & 10 & 0 & 19 & 123 & 10 \\
\hline 56 & 0.92480 & 0.92496 & 19 & 0.92347 & 9 & -16 & 19 & 133 & 9 \\
\hline 57 & 0.91917 & 0.91951 & 18 & 0.91808 & 10 & -34 & 18 & 109 & 10 \\
\hline 58 & 0.91362 & 0.91395 & 19 & 0.91242 & 10 & -33 & 19 & 120 & 10 \\
\hline 59 & 0.90816 & 0.90831 & 20 & 0.90705 & 9 & -15 & 20 & 111 & 9 \\
\hline 60 & 0.90267 & 0.90286 & 18 & 0.90158 & 9 & -19 & 18 & 109 & 9 \\
\hline
\end{tabular}

\section{3. $\mathrm{U}_{3} \mathrm{Si}_{2}-\mathrm{BeO}-\mathrm{UB}_{2}$}

Table 9. Comparison of $2 \mathrm{D} 17 \times 17 \mathrm{U}_{3} \mathrm{Si}_{2}-\mathrm{BeO}-\mathrm{UB}_{2}$ results

\begin{tabular}{|c|c|c|c|c|c|c|c|c|c|}
\hline \multirow{2}{*}{$\begin{array}{c}\text { BU } \\
(\mathbf{M W d} / \mathbf{k g U})\end{array}$} & \multirow{2}{*}{$\frac{\text { VERA }}{k_{\text {eff }}}$} & \multicolumn{2}{|c|}{ Serpent } & \multicolumn{2}{|c|}{ Shift } & \multicolumn{2}{|c|}{$\begin{array}{c}\text { Difference } \\
\text { (VERA - Serpent) }\end{array}$} & \multicolumn{2}{|c|}{$\begin{array}{c}\text { Difference } \\
\text { (VERA - Shift) } \\
\end{array}$} \\
\hline & & $k_{\text {eff }}$ & $\begin{array}{c}1 \sigma \text { std. } \\
\text { dev. }\end{array}$ & $k_{\text {eff }}$ & $\begin{array}{c}1 \sigma \text { std. } \\
\text { dev. }\end{array}$ & $\delta \mathbf{k}_{\text {eff }}$ & 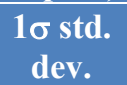 & $\delta \mathbf{k}_{\text {eff }}$ & 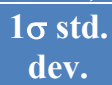 \\
\hline $\mathbf{0}$ & 1.04609 & 1.04709 & 15 & 1.04926 & 9 & -100 & 15 & -317 & 9 \\
\hline 1 & 1.04745 & 1.04881 & 15 & 1.05032 & 9 & -136 & 15 & -287 & 9 \\
\hline 1.5 & 1.05964 & 1.06055 & 15 & 1.06255 & 9 & -91 & 15 & -291 & 9 \\
\hline 2 & 1.07108 & 1.07228 & 15 & 1.07404 & 9 & -120 & 15 & -296 & 9 \\
\hline 2.5 & 1.08163 & 1.08228 & 16 & 1.08478 & 10 & -65 & 16 & -315 & 10 \\
\hline 3 & 1.09128 & 1.09228 & 16 & 1.09432 & 10 & -100 & 16 & -304 & 10 \\
\hline 3.5 & 1.10008 & 1.10059 & 15 & 1.10306 & 9 & -51 & 15 & -298 & 9 \\
\hline 4 & 1.10809 & 1.10890 & 15 & 1.11113 & 10 & -81 & 15 & -304 & 10 \\
\hline 4.5 & 1.11538 & 1.11609 & 14 & 1.11842 & 10 & -71 & 14 & -304 & 10 \\
\hline 5 & 1.12198 & 1.12328 & 14 & 1.12497 & 10 & -130 & 14 & -299 & 10 \\
\hline 5.5 & 1.12795 & 1.12880 & 13 & 1.13124 & 10 & -85 & 13 & -329 & 10 \\
\hline 6 & 1.13334 & 1.13433 & 13 & 1.13666 & 10 & -99 & 13 & -332 & 10 \\
\hline 6.5 & 1.13817 & 1.13898 & 13 & 1.14158 & 10 & -81 & 13 & -341 & 10 \\
\hline 7 & 1.14249 & 1.14362 & 12 & 1.14606 & 10 & -113 & 12 & -357 & 10 \\
\hline 7.5 & 1.14633 & 1.14727 & 13 & 1.14976 & 11 & -94 & 13 & -343 & 11 \\
\hline 8 & 1.14972 & 1.15092 & 14 & 1.15320 & 10 & -120 & 14 & -348 & 10 \\
\hline 8.5 & 1.15268 & 1.15356 & 14 & 1.15624 & 10 & -88 & 14 & -356 & 10 \\
\hline 9 & 1.15524 & 1.15620 & 15 & 1.15877 & 10 & -96 & 15 & -353 & 10 \\
\hline 9.5 & 1.15743 & 1.15809 & 14 & 1.16118 & 10 & -66 & 14 & -375 & 10 \\
\hline 10 & 1.15927 & 1.15998 & 14 & 1.16266 & 11 & -71 & 14 & -339 & 11 \\
\hline 11 & 1.16196 & 1.16306 & 15 & 1.16531 & 10 & -110 & 15 & -335 & 10 \\
\hline 12 & 1.16349 & 1.16441 & 14 & 1.16695 & 10 & -92 & 14 & -346 & 10 \\
\hline 13 & 1.16399 & 1.16510 & 15 & 1.16748 & 10 & -111 & 15 & -349 & 10 \\
\hline 14 & 1.16356 & 1.16450 & 14 & 1.16712 & 10 & -94 & 14 & -356 & 10 \\
\hline
\end{tabular}




\begin{tabular}{|c|c|c|c|c|c|c|c|c|c|}
\hline \multirow{2}{*}{$\begin{array}{c}\text { BU } \\
(\mathrm{MWd} / \mathrm{kgU})\end{array}$} & \multirow{2}{*}{$\frac{\text { VERA }}{\mathbf{k}_{\mathrm{eff}}}$} & \multicolumn{2}{|c|}{ Serpent } & \multicolumn{2}{|c|}{ Shift } & \multicolumn{2}{|c|}{$\begin{array}{c}\text { Difference } \\
\text { (VERA - Serpent) } \\
\end{array}$} & \multicolumn{2}{|c|}{$\begin{array}{c}\text { Difference } \\
\text { (VERA - Shift) } \\
\end{array}$} \\
\hline & & $\mathbf{k}_{\mathrm{eff}}$ & $\begin{array}{l}1 \sigma \text { std. } \\
\text { dev. }\end{array}$ & $\mathbf{k}_{\text {eff }}$ & $\begin{array}{l}1 \sigma \text { std. } \\
\text { dev. }\end{array}$ & $\delta \mathbf{k}_{\text {eff }}$ & 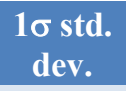 & $\delta \mathbf{k}_{\text {eff }}$ & $\begin{array}{l}1 \sigma \text { std. } \\
\text { dev. }\end{array}$ \\
\hline 15 & 1.16231 & 1.16321 & 13 & 1.16583 & 11 & -90 & 13 & -352 & 11 \\
\hline 16 & 1.16034 & 1.16139 & 15 & 1.16381 & 11 & -105 & 15 & -347 & 11 \\
\hline 17 & 1.15773 & 1.15875 & 15 & 1.16121 & 11 & -102 & 15 & -348 & 11 \\
\hline 18 & 1.15456 & 1.15544 & 15 & 1.15794 & 11 & -88 & 15 & -338 & 11 \\
\hline 19 & 1.15090 & 1.15197 & 14 & 1.15408 & 11 & -107 & 14 & -318 & 11 \\
\hline 20 & 1.14684 & 1.14777 & 14 & 1.14962 & 11 & -93 & 14 & -278 & 11 \\
\hline 21 & 1.14238 & 1.14354 & 16 & 1.14505 & 10 & -116 & 16 & -267 & 10 \\
\hline 22 & 1.13758 & 1.13860 & 16 & 1.14031 & 10 & -102 & 16 & -273 & 10 \\
\hline 23 & 1.13251 & 1.13343 & 16 & 1.13514 & 11 & -92 & 16 & -263 & 11 \\
\hline 24 & 1.12718 & 1.12815 & 16 & 1.12949 & 11 & -97 & 16 & -231 & 11 \\
\hline 25 & 1.12165 & 1.12256 & 14 & 1.12393 & 11 & -91 & 14 & -228 & 11 \\
\hline 26 & 1.11593 & 1.11662 & 16 & 1.11815 & 11 & -69 & 16 & -222 & 11 \\
\hline 27 & 1.11006 & 1.11097 & 15 & 1.11200 & 11 & -91 & 15 & -194 & 11 \\
\hline 28 & 1.10406 & 1.10488 & 15 & 1.10597 & 11 & -82 & 15 & -191 & 11 \\
\hline 29 & 1.09795 & 1.09843 & 14 & 1.09973 & 10 & -48 & 14 & -178 & 10 \\
\hline 30 & 1.09131 & 1.09249 & 15 & 1.09314 & 11 & -118 & 15 & -183 & 11 \\
\hline 31 & 1.08502 & 1.08631 & 15 & 1.08713 & 10 & -129 & 15 & -211 & 10 \\
\hline 32 & 1.07867 & 1.07998 & 16 & 1.08042 & 11 & -131 & 16 & -175 & 11 \\
\hline 33 & 1.07228 & 1.07359 & 16 & 1.07403 & 10 & -131 & 16 & -175 & 10 \\
\hline 34 & 1.06586 & 1.06710 & 16 & 1.06751 & 10 & -124 & 16 & -165 & 10 \\
\hline 35 & 1.05942 & 1.06044 & 17 & 1.06083 & 10 & -102 & 17 & -141 & 10 \\
\hline 36 & 1.05296 & 1.05404 & 17 & 1.05421 & 10 & -108 & 17 & -125 & 10 \\
\hline 37 & 1.04649 & 1.04754 & 17 & 1.04748 & 10 & -105 & 17 & -99 & 10 \\
\hline 38 & 1.04003 & 1.04109 & 17 & 1.04112 & 10 & -106 & 17 & -109 & 10 \\
\hline 39 & 1.03358 & 1.03469 & 16 & 1.03456 & 10 & -111 & 16 & -98 & 10 \\
\hline 40 & 1.02706 & 1.02826 & 18 & 1.02797 & 10 & -120 & 18 & -91 & 10 \\
\hline 41 & 1.02065 & 1.02168 & 16 & 1.02135 & 10 & -103 & 16 & -70 & 10 \\
\hline 42 & 1.01426 & 1.01502 & 17 & 1.01485 & 10 & -76 & 17 & -59 & 10 \\
\hline 43 & 1.00789 & 1.00862 & 18 & 1.00854 & 10 & -73 & 18 & -65 & 10 \\
\hline 44 & 1.00157 & 1.00241 & 17 & 1.00215 & 10 & -84 & 17 & -58 & 10 \\
\hline 45 & 0.99528 & 0.99593 & 17 & 0.99567 & 10 & -65 & 17 & -39 & 10 \\
\hline 46 & 0.98903 & 0.98961 & 17 & 0.98948 & 10 & -58 & 17 & -45 & 10 \\
\hline 47 & 0.98283 & 0.98334 & 18 & 0.98304 & 10 & -51 & 18 & -21 & 10 \\
\hline 48 & 0.97667 & 0.97720 & 18 & 0.97692 & 9 & -53 & 18 & -24 & 9 \\
\hline 49 & 0.97057 & 0.97117 & 18 & 0.97046 & 9 & -60 & 18 & 11 & 9 \\
\hline 50 & 0.96459 & 0.96515 & 17 & 0.96461 & 10 & -56 & 17 & -2 & 10 \\
\hline 51 & 0.95861 & 0.95914 & 17 & 0.95873 & 9 & -53 & 17 & -12 & 9 \\
\hline 52 & 0.95269 & 0.95301 & 18 & 0.95267 & 10 & -32 & 18 & 3 & 10 \\
\hline 53 & 0.94682 & 0.94700 & 19 & 0.94681 & 9 & -18 & 19 & 1 & 9 \\
\hline 54 & 0.94103 & 0.94111 & 18 & 0.94102 & 10 & -8 & 18 & 1 & 10 \\
\hline 55 & 0.93530 & 0.93509 & 16 & 0.93506 & 9 & 21 & 16 & 24 & 9 \\
\hline
\end{tabular}




\begin{tabular}{|c|c|c|c|c|c|c|c|c|c|}
\hline \multirow{2}{*}{$\begin{array}{c}\text { BU } \\
(\mathbf{M W d} / \mathbf{k g U})\end{array}$} & \multirow{2}{*}{$\frac{\text { VERA }}{k_{\text {eff }}}$} & \multicolumn{2}{|c|}{ Serpent } & \multicolumn{2}{|c|}{ Shift } & \multicolumn{2}{|c|}{$\begin{array}{c}\text { Difference } \\
\text { (VERA - Serpent) }\end{array}$} & \multicolumn{2}{|c|}{$\begin{array}{c}\text { Difference } \\
\text { (VERA - Shift) }\end{array}$} \\
\hline & & $\mathbf{k}_{\text {eff }}$ & $\begin{array}{l}1 \sigma \text { std. } \\
\text { dev. }\end{array}$ & $\mathbf{k}_{\text {eff }}$ & $\begin{array}{l}1 \sigma \text { std. } \\
\text { dev. }\end{array}$ & $\delta \mathbf{k}_{\text {eff }}$ & $\begin{array}{l}1 \sigma \text { std. } \\
\text { dev. }\end{array}$ & $\delta \mathbf{k}_{\text {eff }}$ & $\begin{array}{l}\text { 10 std. } \\
\text { dev. }\end{array}$ \\
\hline 56 & 0.92964 & 0.92981 & 18 & 0.92946 & 9 & -17 & 18 & 18 & 9 \\
\hline 57 & 0.92405 & 0.92404 & 18 & 0.92355 & 9 & 1 & 18 & 51 & 9 \\
\hline 58 & 0.91854 & 0.91849 & 18 & 0.91834 & 9 & 5 & 18 & 20 & 9 \\
\hline 59 & 0.91310 & 0.91326 & 19 & 0.91272 & 9 & -16 & 19 & 38 & 9 \\
\hline 60 & 0.90776 & 0.90788 & 19 & 0.90722 & 10 & -12 & 19 & 54 & 10 \\
\hline
\end{tabular}

\section{4. $\mathrm{U}^{15} \mathrm{~N}-\mathrm{BeO}$}

\section{Table 10. Comparison of $2 \mathrm{D} 17 \times 17 \mathrm{U}^{15} \mathrm{~N}-\mathrm{BeO}$ results}

\begin{tabular}{|c|c|c|c|c|c|c|c|c|c|}
\hline \multirow{2}{*}{$\begin{array}{c}\text { BU } \\
(\mathrm{MWd} / \mathrm{kgU})\end{array}$} & \multirow{2}{*}{$\begin{array}{c}\text { VERA } \\
k_{\text {eff }}\end{array}$} & \multicolumn{2}{|c|}{ Serpent } & \multicolumn{2}{|c|}{ Shift } & \multicolumn{2}{|c|}{$\begin{array}{c}\text { Difference } \\
\text { (VERA - Serpent) }\end{array}$} & \multicolumn{2}{|c|}{$\begin{array}{c}\text { Difference } \\
\text { (VERA - Shift) }\end{array}$} \\
\hline & & $\mathbf{k}_{\text {eff }}$ & $\begin{array}{c}1 \sigma \text { std. } \\
\text { dev. }\end{array}$ & $\mathbf{k}_{\text {eff }}$ & $\begin{array}{l}1 \sigma \text { std. } \\
\text { dev. }\end{array}$ & $\delta \mathbf{k}_{\text {eff }}$ & $\begin{array}{l}1 \sigma \text { std. } \\
\text { dev. }\end{array}$ & $\delta \mathbf{k}_{\mathrm{eff}}$ & $\begin{array}{l}1 \sigma \text { std. } \\
\text { dev. }\end{array}$ \\
\hline 0 & 1.42587 & 1.42825 & 12 & 1.42935 & 12 & -238 & 12 & -348 & 12 \\
\hline 1 & 1.36466 & 1.36669 & 12 & 1.36703 & 13 & -203 & 12 & -237 & 13 \\
\hline 1.5 & 1.35900 & 1.36102 & 12 & 1.36120 & 13 & -202 & 12 & -220 & 13 \\
\hline 2 & 1.35368 & 1.35535 & 13 & 1.35608 & 13 & -167 & 13 & -240 & 13 \\
\hline 2.5 & 1.34834 & 1.34993 & 12 & 1.35022 & 12 & -159 & 12 & -188 & 12 \\
\hline 3 & 1.34293 & 1.34450 & 11 & 1.34474 & 12 & -157 & 11 & -181 & 12 \\
\hline 3.5 & 1.33745 & 1.33872 & 11 & 1.33904 & 12 & -127 & 11 & -159 & 12 \\
\hline 4 & 1.33193 & 1.33294 & 12 & 1.33332 & 12 & -101 & 12 & -139 & 12 \\
\hline 4.5 & 1.32639 & 1.32716 & 13 & 1.32760 & 12 & -77 & 13 & -121 & 12 \\
\hline 5 & 1.32085 & 1.32139 & 13 & 1.32219 & 12 & -54 & 13 & -134 & 12 \\
\hline 5.5 & 1.31533 & 1.31592 & 12 & 1.31660 & 12 & -59 & 12 & -127 & 12 \\
\hline 6 & 1.30984 & 1.31045 & 12 & 1.31084 & 11 & -61 & 12 & -100 & 11 \\
\hline 6.5 & 1.30439 & 1.30503 & 13 & 1.30584 & 12 & -64 & 13 & -145 & 12 \\
\hline 7 & 1.29900 & 1.29960 & 13 & 1.29997 & 12 & -60 & 13 & -97 & 12 \\
\hline 7.5 & 1.29365 & 1.29428 & 13 & 1.29470 & 11 & -63 & 13 & -105 & 11 \\
\hline 8 & 1.28837 & 1.28895 & 13 & 1.28933 & 12 & -58 & 13 & -96 & 12 \\
\hline 8.5 & 1.28315 & 1.28364 & 13 & 1.28402 & 12 & -49 & 13 & -87 & 12 \\
\hline 9 & 1.27799 & 1.27832 & 12 & 1.27885 & 12 & -33 & 12 & -86 & 12 \\
\hline 9.5 & 1.27290 & 1.27341 & 13 & 1.27382 & 11 & -51 & 13 & -92 & 11 \\
\hline 10 & 1.26788 & 1.26849 & 14 & 1.26834 & 11 & -61 & 14 & -46 & 11 \\
\hline 11 & 1.25802 & 1.25843 & 14 & 1.25856 & 12 & -41 & 14 & -54 & 12 \\
\hline 12 & 1.24840 & 1.24886 & 13 & 1.24899 & 12 & -46 & 13 & -59 & 12 \\
\hline 13 & 1.23900 & 1.23924 & 14 & 1.23964 & 11 & -24 & 14 & -64 & 11 \\
\hline 14 & 1.22982 & 1.23034 & 13 & 1.23040 & 12 & -52 & 13 & -58 & 12 \\
\hline 15 & 1.22084 & 1.22126 & 14 & 1.22145 & 12 & -42 & 14 & -61 & 12 \\
\hline 16 & 1.21204 & 1.21240 & 14 & 1.21262 & 11 & -36 & 14 & -58 & 11 \\
\hline 17 & 1.20342 & 1.20380 & 14 & 1.20413 & 12 & -38 & 14 & -71 & 12 \\
\hline 18 & 1.19494 & 1.19508 & 15 & 1.19573 & 11 & -14 & 15 & -79 & 11 \\
\hline
\end{tabular}




\begin{tabular}{|c|c|c|c|c|c|c|c|c|c|}
\hline \multirow{2}{*}{$\begin{array}{c}\text { BU } \\
(\mathrm{MWd} / \mathbf{k g U})\end{array}$} & \multirow{2}{*}{$\frac{\text { VERA }}{\mathbf{k}_{\mathrm{eff}}}$} & \multicolumn{2}{|c|}{ Serpent } & \multicolumn{2}{|c|}{ Shift } & \multicolumn{2}{|c|}{$\begin{array}{c}\text { Difference } \\
\text { (VERA - Serpent) }\end{array}$} & \multicolumn{2}{|c|}{$\begin{array}{c}\text { Difference } \\
\text { (VERA - Shift) } \\
\end{array}$} \\
\hline & & $\mathbf{k}_{\mathrm{eff}}$ & $\begin{array}{l}1 \sigma \text { std. } \\
\text { dev. }\end{array}$ & $\mathbf{k}_{\text {eff }}$ & $\begin{array}{c}1 \sigma \text { std. } \\
\text { dev. }\end{array}$ & $\delta \mathbf{k}_{\text {eff }}$ & 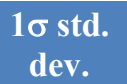 & $\delta \mathbf{k}_{\text {eff }}$ & 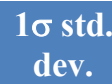 \\
\hline 19 & 1.18661 & 1.18683 & 14 & 1.18725 & 11 & -22 & 14 & -64 & 11 \\
\hline 20 & 1.17823 & 1.17855 & 15 & 1.17880 & 11 & -32 & 15 & -57 & 11 \\
\hline 21 & 1.17014 & 1.17043 & 15 & 1.17071 & 11 & -29 & 15 & -57 & 11 \\
\hline 22 & 1.16216 & 1.16257 & 15 & 1.16286 & 10 & -41 & 15 & -70 & 10 \\
\hline 23 & 1.15427 & 1.15471 & 15 & 1.15479 & 10 & -44 & 15 & -52 & 10 \\
\hline 24 & 1.14648 & 1.14691 & 15 & 1.14706 & 11 & -43 & 15 & -58 & 11 \\
\hline 25 & 1.13878 & 1.13949 & 14 & 1.13915 & 11 & -71 & 14 & -37 & 11 \\
\hline 26 & 1.13115 & 1.13163 & 15 & 1.13149 & 11 & -48 & 15 & -34 & 11 \\
\hline 27 & 1.12360 & 1.12426 & 15 & 1.12394 & 11 & -66 & 15 & -34 & 11 \\
\hline 28 & 1.11612 & 1.11690 & 15 & 1.11661 & 11 & -78 & 15 & -49 & 11 \\
\hline 29 & 1.10871 & 1.10938 & 15 & 1.10896 & 11 & -67 & 15 & -25 & 11 \\
\hline 30 & 1.10101 & 1.10181 & 15 & 1.10142 & 11 & -80 & 15 & -41 & 11 \\
\hline 31 & 1.09370 & 1.09449 & 14 & 1.09403 & 11 & -79 & 14 & -33 & 11 \\
\hline 32 & 1.08645 & 1.08750 & 16 & 1.08689 & 11 & -105 & 16 & -44 & 11 \\
\hline 33 & 1.07926 & 1.08036 & 17 & 1.07950 & 11 & -110 & 17 & -24 & 11 \\
\hline 34 & 1.07212 & 1.07301 & 16 & 1.07241 & 10 & -89 & 16 & -29 & 10 \\
\hline 35 & 1.06504 & 1.06586 & 17 & 1.06541 & 10 & -82 & 17 & -37 & 10 \\
\hline 36 & 1.05801 & 1.05898 & 17 & 1.05815 & 10 & -97 & 17 & -14 & 10 \\
\hline 37 & 1.05102 & 1.05183 & 16 & 1.05104 & 10 & -81 & 16 & -2 & 10 \\
\hline 38 & 1.04409 & 1.04480 & 16 & 1.04419 & 10 & -71 & 16 & -10 & 10 \\
\hline 39 & 1.03722 & 1.03806 & 16 & 1.03714 & 10 & -84 & 16 & 8 & 10 \\
\hline 40 & 1.03053 & 1.03152 & 18 & 1.03039 & 10 & -99 & 18 & 14 & 10 \\
\hline 41 & 1.02376 & 1.02455 & 17 & 1.02358 & 10 & -79 & 17 & 18 & 10 \\
\hline 42 & 1.01705 & 1.01753 & 18 & 1.01679 & 10 & -48 & 18 & 26 & 10 \\
\hline 43 & 1.01038 & 1.01090 & 18 & 1.01010 & 10 & -52 & 18 & 28 & 10 \\
\hline 44 & 1.00378 & 1.00456 & 17 & 1.00350 & 10 & -78 & 17 & 28 & 10 \\
\hline 45 & 0.99723 & 0.99789 & 17 & 0.99688 & 10 & -66 & 17 & 35 & 10 \\
\hline 46 & 0.99073 & 0.99139 & 18 & 0.99025 & 10 & -66 & 18 & 48 & 10 \\
\hline 47 & 0.98430 & 0.98477 & 17 & 0.98380 & 10 & -47 & 17 & 50 & 10 \\
\hline 48 & 0.97793 & 0.97835 & 16 & 0.97750 & 10 & -42 & 16 & 43 & 10 \\
\hline 49 & 0.97162 & 0.97215 & 16 & 0.97107 & 10 & -53 & 16 & 55 & 10 \\
\hline 50 & 0.96549 & 0.96589 & 18 & 0.96492 & 9 & -40 & 18 & 57 & 9 \\
\hline 51 & 0.95932 & 0.95984 & 19 & 0.95853 & 9 & -52 & 19 & 79 & 9 \\
\hline 52 & 0.95322 & 0.95387 & 20 & 0.95258 & 10 & -65 & 20 & 64 & 10 \\
\hline 53 & 0.94719 & 0.94773 & 19 & 0.94662 & 9 & -54 & 19 & 57 & 9 \\
\hline 54 & 0.94123 & 0.94154 & 17 & 0.94035 & 10 & -31 & 17 & 88 & 10 \\
\hline 55 & 0.93535 & 0.93572 & 19 & 0.93462 & 9 & -37 & 19 & 73 & 9 \\
\hline 56 & 0.92954 & 0.92999 & 18 & 0.92880 & 9 & -45 & 18 & 74 & 9 \\
\hline 57 & 0.92382 & 0.92438 & 19 & 0.92315 & 9 & -56 & 19 & 67 & 9 \\
\hline 58 & 0.91818 & 0.91873 & 18 & 0.91742 & 9 & -55 & 18 & 76 & 9 \\
\hline 59 & 0.91262 & 0.91313 & 17 & 0.91191 & 9 & -51 & 17 & 71 & 9 \\
\hline
\end{tabular}




\begin{tabular}{|c|c|c|c|c|c|c|c|c|c|}
\hline \multirow{2}{*}{$\begin{array}{c}\mathrm{BU} \\
(\mathrm{MWd} / \mathrm{kgU})\end{array}$} & \multirow{2}{*}{$\frac{\text { VERA }}{\mathbf{k}_{\mathrm{eff}}}$} & \multicolumn{2}{|c|}{ Serpent } & \multicolumn{2}{|c|}{ Shift } & \multicolumn{2}{|c|}{$\begin{array}{c}\text { Difference } \\
\text { (VERA - Serpent) }\end{array}$} & \multicolumn{2}{|c|}{$\begin{array}{c}\text { Difference } \\
\text { (VERA - Shift) }\end{array}$} \\
\hline & & $k_{\text {eff }}$ & $\begin{array}{l}\text { 10 std. } \\
\text { dev. }\end{array}$ & $k_{\text {eff }}$ & $\begin{array}{l}\text { 10 std. } \\
\text { dev. }\end{array}$ & $\delta \mathbf{k}_{\text {eff }}$ & $\begin{array}{l}1 \sigma \text { std. } \\
\text { dev. }\end{array}$ & $\delta \mathbf{k}_{\text {eff }}$ & 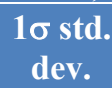 \\
\hline 60 & 0.90714 & 0.90784 & 18 & 0.90635 & 9 & -70 & 18 & 79 & 9 \\
\hline
\end{tabular}

\subsection{U ${ }^{15} \mathrm{~N}-\mathrm{BeO}-\mathrm{UB}_{2}$}

Table 11. Comparison of $2 \mathrm{D} 17 \times 17 \mathrm{U}^{15} \mathrm{~N}-\mathrm{BeO}-\mathrm{UB}_{2}$ results

\begin{tabular}{|c|c|c|c|c|c|c|c|c|c|}
\hline \multirow{2}{*}{$\begin{array}{c}\text { BU } \\
(\mathbf{M W d} / \mathbf{k g U})\end{array}$} & \multirow{2}{*}{$\frac{\text { VERA }}{\mathbf{k}_{\text {eff }}}$} & \multicolumn{2}{|c|}{ Serpent } & \multicolumn{2}{|c|}{ Shift } & \multicolumn{2}{|c|}{$\begin{array}{c}\text { Difference } \\
\text { (VERA - Serpent) }\end{array}$} & \multicolumn{2}{|c|}{$\begin{array}{c}\text { Difference } \\
\text { (VERA - Shift) }\end{array}$} \\
\hline & & $k_{\text {eff }}$ & $\begin{array}{c}1 \sigma \text { std. } \\
\text { dev. }\end{array}$ & $\mathbf{k}_{\mathrm{eff}}$ & $\begin{array}{l}1 \sigma \text { std. } \\
\text { dev. }\end{array}$ & $\delta \mathbf{k}_{\mathrm{eff}}$ & 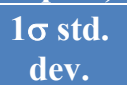 & $\delta \mathbf{k}_{\text {eff }}$ & $\begin{array}{l}\text { 10 std. } \\
\text { dev. }\end{array}$ \\
\hline 0 & 1.07956 & 1.08114 & 15 & 1.08296 & 10 & -158 & 15 & -340 & 10 \\
\hline 1 & 1.07783 & 1.07943 & 15 & 1.08101 & 9 & -160 & 15 & -318 & 9 \\
\hline 1.5 & 1.08908 & 1.09027 & 15 & 1.09251 & 10 & -119 & 15 & -343 & 10 \\
\hline 2 & 1.09961 & 1.10111 & 14 & 1.10286 & 9 & -150 & 14 & -325 & 9 \\
\hline 2.5 & 1.10926 & 1.11024 & 14 & 1.11248 & 9 & -98 & 14 & -322 & 9 \\
\hline 3 & 1.11803 & 1.11938 & 14 & 1.12139 & 10 & -135 & 14 & -336 & 10 \\
\hline 3.5 & 1.12597 & 1.12678 & 14 & 1.12934 & 10 & -81 & 14 & -337 & 10 \\
\hline 4 & 1.13314 & 1.13417 & 15 & 1.13655 & 10 & -103 & 15 & -341 & 10 \\
\hline 4.5 & 1.13960 & 1.14042 & 15 & 1.14298 & 10 & -82 & 15 & -338 & 10 \\
\hline 5 & 1.14541 & 1.14667 & 15 & 1.14895 & 10 & -126 & 15 & -354 & 10 \\
\hline 5.5 & 1.15061 & 1.15154 & 15 & 1.15400 & 10 & -93 & 15 & -339 & 10 \\
\hline 6 & 1.15524 & 1.15641 & 15 & 1.15877 & 10 & -117 & 15 & -353 & 10 \\
\hline 6.5 & 1.15935 & 1.16030 & 15 & 1.16292 & 10 & -95 & 15 & -357 & 10 \\
\hline 7 & 1.16298 & 1.16418 & 14 & 1.16644 & 11 & -120 & 14 & -346 & 11 \\
\hline 7.5 & 1.16614 & 1.16702 & 14 & 1.16965 & 10 & -88 & 14 & -351 & 10 \\
\hline 8 & 1.16888 & 1.16985 & 14 & 1.17246 & 10 & -97 & 14 & -358 & 10 \\
\hline 8.5 & 1.17123 & 1.17216 & 14 & 1.17489 & 10 & -93 & 14 & -366 & 10 \\
\hline 9 & 1.17320 & 1.17446 & 15 & 1.17695 & 11 & -126 & 15 & -375 & 11 \\
\hline 9.5 & 1.17482 & 1.17585 & 14 & 1.17847 & 10 & -103 & 14 & -365 & 10 \\
\hline 10 & 1.17594 & 1.17724 & 14 & 1.17962 & 11 & -130 & 14 & -368 & 11 \\
\hline 11 & 1.17759 & 1.17899 & 16 & 1.18133 & 11 & -140 & 16 & -374 & 11 \\
\hline 12 & 1.17818 & 1.17933 & 15 & 1.18194 & 10 & -115 & 15 & -376 & 10 \\
\hline 13 & 1.17782 & 1.17909 & 14 & 1.18150 & 10 & -127 & 14 & -368 & 10 \\
\hline 14 & 1.17660 & 1.17777 & 14 & 1.18028 & 10 & -117 & 14 & -368 & 10 \\
\hline 15 & 1.17465 & 1.17586 & 14 & 1.17818 & 11 & -121 & 14 & -353 & 11 \\
\hline 16 & 1.17204 & 1.17365 & 13 & 1.17560 & 10 & -161 & 13 & -356 & 10 \\
\hline 17 & 1.16886 & 1.16996 & 13 & 1.17229 & 11 & -110 & 13 & -343 & 11 \\
\hline 18 & 1.16517 & 1.16658 & 15 & 1.16864 & 11 & -141 & 15 & -347 & 11 \\
\hline 19 & 1.16104 & 1.16219 & 16 & 1.16425 & 11 & -115 & 16 & -321 & 11 \\
\hline 20 & 1.15653 & 1.15789 & 14 & 1.15961 & 11 & -136 & 14 & -308 & 11 \\
\hline 21 & 1.15168 & 1.15286 & 14 & 1.15469 & 10 & -118 & 14 & -301 & 10 \\
\hline 22 & 1.14655 & 1.14768 & 15 & 1.14945 & 11 & -113 & 15 & -290 & 11 \\
\hline
\end{tabular}




\begin{tabular}{|c|c|c|c|c|c|c|c|c|c|}
\hline \multirow{2}{*}{$\begin{array}{c}\text { BU } \\
(\mathrm{MWd} / \mathbf{k g U})\end{array}$} & \multirow{2}{*}{$\frac{\text { VERA }}{k_{\text {eff }}}$} & \multicolumn{2}{|c|}{ Serpent } & \multicolumn{2}{|c|}{ Shift } & \multicolumn{2}{|c|}{$\begin{array}{c}\text { Difference } \\
\text { (VERA - Serpent) }\end{array}$} & \multicolumn{2}{|c|}{$\begin{array}{c}\text { Difference } \\
\text { (VERA - Shift) } \\
\end{array}$} \\
\hline & & $k_{\text {eff }}$ & $\begin{array}{c}1 \sigma \text { std. } \\
\text { dev. }\end{array}$ & $\mathbf{k}_{\text {eff }}$ & $\begin{array}{c}1 \sigma \text { std. } \\
\text { dev. }\end{array}$ & $\delta \mathbf{k}_{\text {eff }}$ & $\begin{array}{l}1 \sigma \text { std. } \\
\text { dev. }\end{array}$ & $\delta \mathbf{k}_{\text {eff }}$ & 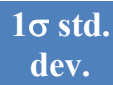 \\
\hline 23 & 1.14116 & 1.14240 & 15 & 1.14418 & 10 & -124 & 15 & -302 & 10 \\
\hline 24 & 1.13555 & 1.13688 & 14 & 1.13845 & 11 & -133 & 14 & -290 & 11 \\
\hline 25 & 1.12975 & 1.13074 & 14 & 1.13249 & 11 & -99 & 14 & -274 & 11 \\
\hline 26 & 1.12380 & 1.12499 & 15 & 1.12633 & 11 & -119 & 15 & -253 & 11 \\
\hline 27 & 1.11771 & 1.11880 & 15 & 1.12001 & 10 & -109 & 15 & -230 & 10 \\
\hline 28 & 1.11151 & 1.11260 & 15 & 1.11374 & 11 & -109 & 15 & -223 & 11 \\
\hline 29 & 1.10522 & 1.10651 & 14 & 1.10730 & 10 & -129 & 14 & -208 & 10 \\
\hline 30 & 1.09881 & 1.10033 & 13 & 1.10076 & 11 & -152 & 13 & -195 & 11 \\
\hline 31 & 1.09237 & 1.09383 & 16 & 1.09428 & 10 & -146 & 16 & -191 & 10 \\
\hline 32 & 1.08589 & 1.08704 & 16 & 1.08768 & 11 & -115 & 16 & -179 & 11 \\
\hline 33 & 1.07938 & 1.08034 & 16 & 1.08099 & 10 & -96 & 16 & -161 & 10 \\
\hline 34 & 1.07283 & 1.07381 & 17 & 1.07444 & 11 & -98 & 17 & -161 & 11 \\
\hline 35 & 1.06627 & 1.06719 & 15 & 1.06761 & 11 & -92 & 15 & -134 & 11 \\
\hline 36 & 1.05970 & 1.06031 & 17 & 1.06086 & 10 & -61 & 17 & -116 & 10 \\
\hline 37 & 1.05312 & 1.05387 & 17 & 1.05437 & 10 & -75 & 17 & -125 & 10 \\
\hline 38 & 1.04656 & 1.04741 & 16 & 1.04739 & 11 & -85 & 16 & -83 & 11 \\
\hline 39 & 1.04000 & 1.04083 & 17 & 1.04088 & 10 & -83 & 17 & -88 & 10 \\
\hline 40 & 1.03334 & 1.03447 & 16 & 1.03433 & 10 & -113 & 16 & -99 & 10 \\
\hline 41 & 1.02682 & 1.02763 & 18 & 1.02747 & 10 & -81 & 18 & -65 & 10 \\
\hline 42 & 1.02033 & 1.02128 & 17 & 1.02094 & 10 & -95 & 17 & -61 & 10 \\
\hline 43 & 1.01387 & 1.01487 & 16 & 1.01442 & 10 & -100 & 16 & -55 & 10 \\
\hline 44 & 1.00744 & 1.00826 & 16 & 1.00780 & 10 & -82 & 16 & -36 & 10 \\
\hline 45 & 1.00105 & 1.00170 & 17 & 1.00150 & 9 & -65 & 17 & -45 & 9 \\
\hline 46 & 0.99470 & 0.99540 & 16 & 0.99496 & 10 & -70 & 16 & -26 & 10 \\
\hline 47 & 0.98840 & 0.98898 & 17 & 0.98849 & 10 & -58 & 17 & -9 & 10 \\
\hline 48 & 0.98215 & 0.98261 & 17 & 0.98222 & 10 & -46 & 17 & -7 & 10 \\
\hline 49 & 0.97594 & 0.97638 & 18 & 0.97595 & 9 & -44 & 18 & -1 & 9 \\
\hline 50 & 0.96959 & 0.97027 & 18 & 0.96982 & 9 & -68 & 18 & -23 & 9 \\
\hline 51 & 0.96350 & 0.96405 & 16 & 0.96359 & 9 & -55 & 16 & -9 & 9 \\
\hline 52 & 0.95747 & 0.95783 & 17 & 0.95751 & 10 & -36 & 17 & -4 & 10 \\
\hline 53 & 0.95150 & 0.95188 & 18 & 0.95157 & 10 & -38 & 18 & -6 & 10 \\
\hline 54 & 0.94559 & 0.94615 & 19 & 0.94556 & 9 & -56 & 19 & 3 & 9 \\
\hline 55 & 0.93976 & 0.94026 & 19 & 0.93983 & 9 & -50 & 19 & -7 & 9 \\
\hline 56 & 0.93399 & 0.93452 & 17 & 0.93399 & 8 & -53 & 17 & 0 & 8 \\
\hline 57 & 0.92830 & 0.92884 & 18 & 0.92821 & 9 & -54 & 18 & 9 & 9 \\
\hline 58 & 0.92269 & 0.92323 & 17 & 0.92281 & 9 & -54 & 17 & -12 & 9 \\
\hline 59 & 0.91715 & 0.91761 & 17 & 0.91706 & 9 & -46 & 17 & 9 & 9 \\
\hline 60 & 0.91170 & 0.91187 & 20 & 0.91134 & 9 & -17 & 20 & 36 & 9 \\
\hline
\end{tabular}




\subsection{DIFFERENCE BETWEEN SHIFT AND SERPENT RESULTS}

Table 12. Comparison of results from Shift and Serpent Monte Carlo codes

\begin{tabular}{|c|c|c|c|c|c|c|c|c|c|c|}
\hline \multirow{2}{*}{$\begin{array}{c}\text { BU } \\
(\mathbf{M W d} / \mathbf{k g U})\end{array}$} & \multicolumn{2}{|c|}{$\mathbf{U O}_{2}$} & \multicolumn{2}{|c|}{$\mathrm{U}_{3} \mathrm{Si}_{2}-\mathrm{BeO}$} & \multicolumn{2}{|c|}{$\begin{array}{c}\mathrm{U}_{3} \mathrm{Si}_{2}-\mathrm{BeO}- \\
\mathrm{UB}_{2}\end{array}$} & \multicolumn{2}{|c|}{$\mathbf{U}^{15} \mathbf{N}-\mathbf{B e O}$} & \multicolumn{2}{|c|}{$\begin{array}{c}\mathbf{U}^{15} \mathrm{~N}-\mathrm{BeO}- \\
\mathrm{UB}_{2}\end{array}$} \\
\hline & $k_{\text {eff }}$ & $\begin{array}{c}1 \sigma \\
\text { stdev. }\end{array}$ & $k_{\mathrm{eff}}$ & $\begin{array}{c}1 \sigma \\
\text { stdev. }\end{array}$ & $\mathbf{k}_{\text {eff }}$ & $\begin{array}{c}1 \sigma \\
\text { stdev. }\end{array}$ & $\mathbf{k}_{\text {eff }}$ & $\begin{array}{c}1 \sigma \\
\text { stdev. }\end{array}$ & $k_{\text {eff }}$ & $\begin{array}{c}1 \sigma \\
\text { stdev. }\end{array}$ \\
\hline 0.0 & 90 & 17 & 99 & 17 & 217 & 18 & 110 & 17 & 182 & 18 \\
\hline 1.0 & 36 & 17 & 28 & 17 & 151 & 18 & 34 & 17 & 158 & 18 \\
\hline 1.5 & 28 & 16 & 16 & 16 & 200 & 18 & 18 & 18 & 224 & 18 \\
\hline 2.0 & 37 & 16 & 71 & 16 & 176 & 18 & 73 & 18 & 175 & 17 \\
\hline 2.5 & 37 & 16 & 42 & 16 & 250 & 19 & 29 & 17 & 224 & 17 \\
\hline 3.0 & 52 & 16 & 25 & 16 & 204 & 19 & 24 & 16 & 201 & 17 \\
\hline 3.5 & 10 & 16 & 36 & 16 & 247 & 18 & 32 & 16 & 256 & 17 \\
\hline 4.0 & -4 & 16 & 30 & 17 & 223 & 18 & 38 & 17 & 238 & 18 \\
\hline 4.5 & 22 & 17 & 22 & 17 & 233 & 17 & 44 & 18 & 256 & 18 \\
\hline 5.0 & 17 & 17 & -5 & 16 & 169 & 17 & 80 & 18 & 228 & 18 \\
\hline 5.5 & 16 & 16 & 52 & 17 & 244 & 16 & 68 & 17 & 246 & 18 \\
\hline 6.0 & 7 & 16 & 54 & 18 & 233 & 17 & 39 & 17 & 236 & 18 \\
\hline 6.5 & 20 & 17 & 36 & 17 & 260 & 17 & 81 & 18 & 262 & 18 \\
\hline 7.0 & 12 & 18 & 12 & 17 & 244 & 16 & 37 & 18 & 226 & 18 \\
\hline 7.5 & 5 & 17 & 31 & 17 & 249 & 17 & 42 & 17 & 263 & 17 \\
\hline 8.0 & 11 & 18 & -13 & 18 & 228 & 17 & 38 & 18 & 261 & 17 \\
\hline 8.5 & 6 & 18 & 7 & 18 & 268 & 17 & 38 & 17 & 273 & 17 \\
\hline 9.0 & 35 & 16 & 56 & 18 & 257 & 18 & 53 & 17 & 249 & 18 \\
\hline 9.5 & -2 & 17 & 36 & 17 & 309 & 17 & 41 & 17 & 262 & 17 \\
\hline 10.0 & 8 & 17 & 33 & 17 & 268 & 18 & -15 & 18 & 238 & 18 \\
\hline 11.0 & -7 & 18 & 7 & 18 & 225 & 18 & 13 & 18 & 234 & 20 \\
\hline 12.0 & -4 & 19 & 45 & 18 & 254 & 17 & 13 & 18 & 261 & 18 \\
\hline 13.0 & 24 & 17 & 33 & 18 & 238 & 18 & 40 & 18 & 241 & 17 \\
\hline 14.0 & 11 & 18 & 11 & 18 & 262 & 17 & 6 & 17 & 251 & 17 \\
\hline 15.0 & 51 & 19 & 60 & 17 & 262 & 17 & 19 & 18 & 232 & 18 \\
\hline 16.0 & 35 & 18 & 10 & 17 & 242 & 19 & 22 & 18 & 195 & 16 \\
\hline 17.0 & 24 & 18 & 62 & 18 & 246 & 19 & 33 & 18 & 233 & 17 \\
\hline 18.0 & 44 & 19 & 35 & 18 & 250 & 19 & 65 & 19 & 206 & 18 \\
\hline 19.0 & -9 & 18 & 9 & 18 & 211 & 18 & 42 & 18 & 206 & 20 \\
\hline 20.0 & 0 & 18 & 33 & 18 & 185 & 18 & 25 & 18 & 172 & 18 \\
\hline 21.0 & -4 & 19 & 1 & 18 & 151 & 19 & 28 & 19 & 183 & 17 \\
\hline 22.0 & -8 & 19 & -11 & 19 & 171 & 19 & 29 & 18 & 177 & 18 \\
\hline 23.0 & -9 & 18 & -24 & 18 & 171 & 19 & 8 & 18 & 178 & 18 \\
\hline 24.0 & -23 & 19 & -20 & 17 & 134 & 19 & 15 & 18 & 157 & 18 \\
\hline 25.0 & -27 & 18 & -3 & 18 & 137 & 18 & -34 & 18 & 175 & 18 \\
\hline 26.0 & -58 & 19 & -17 & 17 & 153 & 19 & -14 & 18 & 134 & 18 \\
\hline 27.0 & -56 & 19 & -22 & 17 & 103 & 19 & -32 & 19 & 121 & 18 \\
\hline 28.0 & -52 & 19 & -14 & 18 & 109 & 18 & -29 & 18 & 114 & 18 \\
\hline
\end{tabular}




\begin{tabular}{|c|c|c|c|c|c|c|c|c|c|c|}
\hline \multirow{2}{*}{$\begin{array}{c}\mathrm{BU} \\
(\mathrm{MWd} / \mathrm{kgU})\end{array}$} & \multicolumn{2}{|c|}{$\mathbf{U O}_{2}$} & \multicolumn{2}{|c|}{$\mathrm{U}_{3} \mathrm{Si}_{2}-\mathrm{BeO}$} & \multicolumn{2}{|c|}{$\begin{array}{c}\mathrm{U}_{3} \mathrm{Si}_{2}-\mathrm{BeO}- \\
\mathrm{UB}_{2}\end{array}$} & \multicolumn{2}{|c|}{$\mathbf{U}^{15} \mathrm{~N}-\mathrm{BeO}$} & \multicolumn{2}{|c|}{$\begin{array}{c}\mathbf{U}^{15} \mathbf{N}-\mathrm{BeO}_{-}- \\
\mathbf{U B}_{2}\end{array}$} \\
\hline & $\mathbf{k}_{\text {eff }}$ & $\begin{array}{c}1 \sigma \\
\text { stdev. }\end{array}$ & $\mathbf{k}_{\mathrm{eff}}$ & $\begin{array}{c}1 \sigma \\
\text { stdev. }\end{array}$ & $\mathbf{k}_{\text {eff }}$ & $\begin{array}{c}1 \sigma \\
\text { stdev. }\end{array}$ & $\mathbf{k}_{\text {eff }}$ & $\begin{array}{c}1 \sigma \\
\text { stdev. }\end{array}$ & $\mathbf{k}_{\text {eff }}$ & $\begin{array}{c}1 \sigma \\
\text { stdev. }\end{array}$ \\
\hline 29.0 & -74 & 19 & -30 & 19 & 130 & 17 & -42 & 18 & 79 & 17 \\
\hline 30.0 & -66 & 18 & -32 & 19 & 65 & 18 & -39 & 18 & 43 & 17 \\
\hline 31.0 & -79 & 18 & -27 & 20 & 82 & 18 & -46 & 18 & 45 & 19 \\
\hline 32.0 & -73 & 19 & -59 & 19 & 44 & 19 & -61 & 19 & 64 & 19 \\
\hline 33.0 & -84 & 19 & -67 & 19 & 44 & 19 & -86 & 20 & 65 & 19 \\
\hline 34.0 & -80 & 19 & -65 & 19 & 41 & 19 & -60 & 19 & 63 & 20 \\
\hline 35.0 & -93 & 19 & -72 & 20 & 39 & 20 & -45 & 20 & 42 & 18 \\
\hline 36.0 & -94 & 18 & -63 & 19 & 17 & 20 & -83 & 20 & 55 & 20 \\
\hline 37.0 & -101 & 19 & -105 & 19 & -6 & 20 & -79 & 19 & 50 & 20 \\
\hline 38.0 & -93 & 19 & -106 & 19 & 3 & 20 & -61 & 19 & -2 & 19 \\
\hline 39.0 & -92 & 18 & -94 & 19 & -13 & 19 & -92 & 19 & 5 & 20 \\
\hline 40.0 & -143 & 19 & -48 & 19 & -29 & 21 & -113 & 21 & -14 & 19 \\
\hline 41.0 & -139 & 21 & -95 & 19 & -33 & 19 & -97 & 20 & -16 & 20 \\
\hline 42.0 & -120 & 19 & -135 & 19 & -17 & 20 & -74 & 20 & -34 & 20 \\
\hline 43.0 & -115 & 19 & -122 & 19 & -8 & 21 & -80 & 21 & -45 & 19 \\
\hline 44.0 & -152 & 20 & -86 & 20 & -26 & 20 & -106 & 20 & -46 & 19 \\
\hline 45.0 & -166 & 22 & -86 & 20 & -26 & 20 & -101 & 20 & -20 & 19 \\
\hline 46.0 & -160 & 20 & -119 & 19 & -13 & 20 & -114 & 20 & -44 & 19 \\
\hline 47.0 & -154 & 20 & -122 & 19 & -30 & 21 & -97 & 20 & -49 & 20 \\
\hline 48.0 & -125 & 20 & -113 & 18 & -28 & 20 & -86 & 19 & -39 & 20 \\
\hline 49.0 & -130 & 21 & -112 & 20 & -71 & 20 & -108 & 19 & -43 & 20 \\
\hline 50.0 & -138 & 20 & -143 & 20 & -54 & 20 & -97 & 20 & -45 & 20 \\
\hline 51.0 & -161 & 21 & -157 & 19 & -41 & 19 & -131 & 21 & -46 & 18 \\
\hline 52.0 & -162 & 20 & -133 & 20 & -35 & 20 & -129 & 22 & -32 & 20 \\
\hline 53.0 & -173 & 20 & -101 & 21 & -19 & 21 & -111 & 21 & -31 & 20 \\
\hline 54.0 & -167 & 21 & -110 & 21 & -9 & 20 & -119 & 20 & -59 & 21 \\
\hline 55.0 & -136 & 21 & -123 & 21 & -3 & 19 & -110 & 21 & -43 & 21 \\
\hline 56.0 & -151 & 19 & -149 & 21 & -35 & 20 & -119 & 20 & -53 & 19 \\
\hline 57.0 & -133 & 19 & -143 & 20 & -50 & 20 & -123 & 21 & -63 & 20 \\
\hline $\mathbf{5 8 . 0}$ & -139 & 20 & -153 & 21 & -15 & 20 & -131 & 20 & -42 & 19 \\
\hline 59.0 & -165 & 21 & -126 & 22 & -54 & 21 & -122 & 19 & -55 & 19 \\
\hline 60.0 & -171 & 21 & -128 & 20 & -66 & 21 & -149 & 20 & -53 & 22 \\
\hline
\end{tabular}




\section{SUMMARY AND FUTURE WORK}

DOE-NE's cooperation with the NRC to facilitate the licensing of ATF concepts and to accelerate the analysis of various design concepts has led to an effort within CASL to identify any M\&S gaps of ATF concepts. This benchmark effort sought to show differences between VERA, Shift, and Serpent in the keff at various burnups during a depletion calculation. CASL's Westinghouse collaborators identified the following ATF concepts for PWRs as benchmark problems for M\&S tools:

- $\mathrm{U}_{3} \mathrm{Si}_{2}-\mathrm{BeO}$ fuel and chromium coated ZIRLO cladding

- $\mathrm{U}_{3} \mathrm{Si}_{2}-\mathrm{BeO}-\mathrm{UB}_{2}$ and chromium coated ZIRLO cladding

- $\mathrm{U}^{15} \mathrm{~N}-\mathrm{BeO}$ and chromium coated ZIRLO cladding

- $\mathrm{U}^{15} \mathrm{~N}-\mathrm{BeO}-\mathrm{UB}_{2}$ and chromium coated ZIRLO cladding

The depletion parameters and flags used to run these models differ between all three codes. There were differences seen in keff between VERA, Shift, and Serpent, especially between VERA and Shift at the first time-step for ATF concepts. The differences identified in this document must be investigated further by modeling single fuel pin depletion to compare the isotopic evolution of the fuel during a depletion calculation. Prior depletion benchmarking efforts between VERA and Shift have shown closer agreement for $\mathrm{UO}_{2}$, so recent changes to the code and the data must be examined to identify the cause of these differences.

\section{ACKNOWLEDGMENTS}

The VERA and Shift cases used resources of the Compute and Data Environment for Science (CADES) at ORNL, which is supported by DOE's Office of Science under Contract No. DE-AC05$00 \mathrm{OR} 22725$.

The authors would like to acknowledge the support received from the MPACT and Shift development teams for this work.

\section{REFERENCES}

1. United States Department of Energy, "Development of Light Water Reactor Fuels with Enhanced Accident Tolerance,” Report to United States Congress (2015).

2. T. Miller, "Advanced Modeling and Simulation, Accident Tolerant Fuel Application," US Department of Energy Office of Nuclear Energy (2018). Presentation available through the NRC website at https://www.nrc.gov/reading-rm/doccollections/commission/slides/2018/20180412/miller-20180412.pdf. Webpage visited in April 2019.

3. The Consortium for Advanced Simulation of Light Water Reactors, <https://www.casl.gov>. Webpage visited in April 2019.

4. J. A. Turner et al., "The Virtual Environment for Reactor Applications (VERA): Design and architecture," Journal of Computational Physics, 326, 544 (2016).

5. J. Leppänen, M. Pusa, T. Viitanen, V. Valtavirta, and T. Kaltiaisenaho, "The Serpent Monte Carlo code: Status, development and applications in 2013," Annals of Nuclear Energy, 82 pp 142-150 (2015). 
6. T. M. Pandya, S. R. Johnson, T. M. Evans, G. G. Davidson, S. P. Hamilton, and A. T. Godfrey, "Capabilities, Implementation, and Benchmarking of Shift, a Massively Parallel Monte Carlo Radiation Transport Code," Journal of Computational Physics, 308, 239 (2016).

7. US Department of Energy Office of Nuclear Energy, "DOE Awards \$111 Million to U.S. Vendors to Develop Accident Tolerant Nuclear Fuels," < https://www.energy.gov/ne/articles/doeawards-111-million-us-vendors-develop-accident-tolerant-nuclear-fuels $>$. Webpage visited in April 2019.

8. NEI, "Accident Tolerant Fuel," < https://www.nei.org/advocacy/make-regulationssmarter/accident-tolerant-fuel $>$. Webpage visited in April 2019.

9. Westinghouse Nuclear, "Accident-tolerant Fuel," <http://www.westinghousenuclear.com/Portals/0/Technovation\%20Stuff/Accident $\% 20$ Tolerant $\%$ 20Fuel\%20Brochure\%20.pdf $>$. Webpage visited in April 2019.

10. J. P. Mazzoccoli, J. Choi and P. Xu, "Progress on the Westinghouse Accident Tolerant Fuel Programme," Accident Tolerant Fuel Concepts for Light Water Reactors - Proceedings of a technical meeting held at ORNL, IAEA-TECDOC-1797 (2014).

11. B. Collins et al., "Stability and Accuracy of 3D Neutron Transport Simulations Using the 2D/1D Method in MPACT," Journal of Computational Physics, 326, 612 (2016).

12. R. K. Salko and M. N. Avramova, "CTF Theory Manual," The Pennsylvania State University (2012).

13. W. Wieselquist, "The SCALE 6.2 ORIGEN API for High Performance Depletion," Proc. $M \& C$ and SNA 2014, Nashville, TN, USA (2015).

14. B. T. Rearden and M. A. Jessee, Eds., SCALE Code System, ORNL/TM-2005/39, Version 6.2.3, Oak Ridge National Laboratory, Oak Ridge, Tennessee (2018). Available from the Radiation Safety Information Computational Center as CCC-834.

15. MCNP Team, MCNP6 Users Manual-Code Version 6.1.1beta, LA-CP-14-00745, Los Alamos National Laboratory (2014).

16. "Serpent: a Continuous-energy Monte Carlo Reactor Physics Burnup Calculation Code," $<$ http://montecarlo.vtt.fi $>$. Webpage visited in April 2019.

17. A. T. Godfrey, "VERA Core Physics Benchmark Progression Problem Specifications," Consortium for Advanced Simulation of Light Water Reactors, CASL-U-2012-0131-004 (2014).

18. F. Franceschini, ATF CASL Fuel Specifications, obtained in January, 2019.

19. M. B. Chadwick et al., "ENDF/B-VII.1 Nuclear Data for Science and Technology: Cross Sections, Covariances, Fission Product Yields and Decay Data," Nuclear Data Sheets, 112 (12), p. 2887-2996 (2011).

20. K. S. Kim et al., "Verification and validation of the ENDF/B-VII.1 v4.3m1 MPACT 51-group cross section library," Consortium for Advanced Simulation of Light Water Reactors, CASL-U2018-1528-000, Oak Ridge National Laboratory (2018).

21. G. G. Davidson, T. M. Pandya, S. R. Johnson, T. M. Evans, A. E. Isotalo, C. A. Gentry, and W. A. Wieselquist, "Nuclide Depletion Capabilities in the Shift Monte Carlo Code," Annals of Nuclear Energy, 114, pp. 259-276 (2018). 